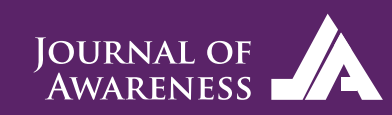

0
0
Journal of Awareness

Volume / Cilt: 6, Issue / Sayl:4, 2021, pp. 229-246

E-ISSN: 2149-6544

https://journals.gen.tr/joa

DOI: https://doi.org/10.26809/joa.6.4.05
Received / Geliș: 01.09.2021 Accepted / Kabul: 21.10.2021

\title{
Toplum 5.0 ve kamu hizmeti: Türkiye üzerine bir değerlendirme
}

\author{
Society 5.0 and Public Services: An assessment on Turkey
}

\section{Özge Uysal Şahin}

Doç. Dr., Çanakkale Onsekiz Mart Üniversitesi, Çanakkale Uygulamalı Bilimler Fakültesi, Sağlık Yönetimi Bölümü, Sağlık Ekonomisi Anabilim Dalı, Çanakkale, Türkiye, e-mail: ozge@comu.edu.tr

$\ddot{O} z$

Bilgi ve iletişim teknolojilerindeki hızlı değişim ciddi bir toplumsal dönüşüm yaratmaktadır. 2000'li başlarında bilgisayar, internet, mobil telefon gibi araçlar neredeyse lüks mahiyetindeyken, günümüzde hayatlarımızın ayrılmaz birer parçaları haline gelmiş ve çok sayıda yeni teknolojik gelişmeyi de arkasından getirmiştir. Artık, yapay zeka, robotlar, nesnelerin interneti, bulut teknolojileri ve büyük veri analizleri gibi çok sayıda ileri düzey bilişim aracı ekonomiden sağlığa, ulaşımdan eğitime kadar her sektörde yaygınlaşmaya başlamıştır. Teknoloji bu yönde hızla ilerlerken tüm dünyada artan doğal afetler, terör olayları, ekonomik krizler ve sosyal sorunlar teknolojinin kullanım amacının ve şeklinin değiştirilmesi gerektiğini gündeme getirmiştir. Bu bağlamda, Japonya tarafından Toplum 5.0 olarak adlandırılan yeni bir teknolojik ve toplumsal dönüşüm hedefi ortaya konmuştur. Dijital teknolojiler temelinde şekillendirilmiş, sürdürülebilir bir toplum anlayışını oluşturmayı hedefleyen Toplum 5.0, insan merkezli yeni bir toplumsal dönüşüm evresini ifade etmektedir. Toplum 5.0' da toplum ile teknolojinin toplum adına işbirliği içinde yer aldığı, teknolojinin toplum için tehdit oluşturmadığı bir ortamın yaratılması amacı vardır. Tüm sektörleri etkileyecek bu dönüşümün özellikle kamu hizmetlerinde etkili olmasının beklendiği ve bunun da bir gereklilik olduğu ifade edilmektedir. Bu çalışmayla da, Toplum 5.0 kavramının teorik çerçevesi detaylı olarak ortaya konularak tüm dünyada kamu sektöründe ne kadar belirleyici olduğu, aksayan ve düzeltilmesi gereken yönlerin neler olduğu ortaya konmaya çalışılmıştır. Tüm bu gelişmeler ışığında, henüz endüstri 4.0'ın emekleme aşamasında olduğu söylenebilecek olan Türkiye'de Toplum 5.0'a geçişte durumunun, mevut sorunların neler olduğu ve bu doğrultuda nasıl bir yol haritası izlemesi gerektiği üzerinde durulmuştur. Birtakım önerilere sunularak konuya 1şık tutulmak istenmiştir.

Anahtar kelimeler: Toplum 5.0, Kamu hizmeti,Türkiye, Teknoloji. 


\begin{abstract}
The rapid change in information and communication technologies creates a serious social transformation. In the early 2000s, tools such as computers, internet and mobile phones were almost a luxury, but today they have become an integral part of our lives and brought many new technological developments behind them. Now, many advanced computing tools such as artificial intelligence, robots, internet of things, cloud technologies and big data analysis have started to become widespread in every sector from economy to health, from transportation to education. While technology is advancing rapidly in this direction, increasing natural disasters, terrorist incidents, economic crises and social problems have brought to the agenda that the purpose and way of using technology should be changed based on these problems. In this context, a new technological and social transformation target called Society 5.0 has been put forward by Japan. Aiming to create a sustainable society perspective shaped on the basis of digital technologies, Society 5.0 represents a new human-centered social transformation phase. Society 5.0 aims to create a society where society and technology cooperate on behalf of society, and where technology does not pose a threat to society. It is stated that this transformation, which will affect all sectors, is expected to be effective especially in public services and this is a necessity. In this study, the theoretical framework of the concept of Society 5.0 has been put forward in detail, and it has been tried to reveal how decisive it is in the public sector all over the world, what are the deficiencies and what needs to be corrected. In the light of all these developments, it has been emphasized what the situation and current problems are in the transition to Society 5.0 in Turkey, which can be said to be in the prime stage of industry 4.0, and what kind of road map should be followed in this direction. It was aimed to shed light on the subject by offering some suggestions.
\end{abstract}

Keywords: Society 5.0, Public services,Turkey, Technology.

\section{GİRIŞ}

Dünya, doğal kaynakların tükenmesi, küresel ısınma, artan ekonomik eşitsizlik ve terör gibi küresel ölçekteki problemlerle giderek daha fazla karşı karşıya kalmaktadır. Artık her düzeyde artan sorunlarla mücadele etmenin yolları ve daha yaşanabilir bir dünyanın nasıl gerçekleştirilebileceği aranmaktadır. Hızla ilerleyen bilgi ve iletişim teknolojilerinin ise bu sorunları tetikleyen mi, yoksa düzelten mi olacağı yönündeki belirsizliği giderme ise insanlığın elindedir. $\mathrm{Bu}$ nedenle, toplumdaki sorunları çözmenin etkili ve verimli bir yolu olarak, yeni bilgiler edinmek ve "insanlar ve nesneler" ile "gerçek ve siber" dünyalar arasında bağlantılar kurarak yeni değerler yaratmak için bilgi ve iletişim teknolojilerinden sonuna kadar yararlanmamız çok önemlidir. Zaten teknolojik değişim ve gelişimin gerisinde kalan toplumlar dünyanın yeni yapısında yerlerini almakta ve entegrasyonu sağlamada zorluk çekeceklerdir. Bu yüzden tüm toplumların değişimin farkına vararak gerekli adımları atmaları önemli bir gereksinim haline gelmiştir. Böylece insanlar için daha iyi yaşamlar yaratmak ve sağlıklı ekonomik büyümeyi sürdürülebilir kılmak mümkün hale gelecektir. Çünkü teknoloji artık günümüzde kabuk değiştirmekte ve daha insan odaklı bir hale gelmektedir.

21. yüzyılın başlarından itibaren nesnelerin interneti, yapay zeka ve robotik gibi teknolojilerin ortaya çıması ve bu teknolojilerin giderek tüm dünyada uygulanır duruma gelmesiyle beraber toplumsal ve ekonomik yapıda küresel olarak bir değişim ve dönüşüm sürecine girilmiştir. Endüstri 4.0 ile başlayan bu süreç Japonya'nın ortaya attığ1 "süper akıllı toplum" felsefesine dayanan Toplum 5.0 çerçevesinde şekillenmektedir. Toplum 5.0, odağına insan ve insanın yaşam kalitesini alması bakımından Endüstri 4.0'dan farklı bir yaklaşıma sahiptir. Teknolojiyi insanlığın faydasına kullanarak toplumun refahını artırmak için insan merkezli bir toplum yaratma anlayışına dayanmaktadır. Yapay zeka ve robotlar insana yardımcı ve sürdürülebilir yaşam koşullarına hizmet edecek şekilde kurgulanmaktadır. Toplum 5.0 ile dünya, teknolojik değişim, ekonomik ve jeopolitik değişim ve de zihniyet değişimi gibi büyük bir değişim dalgasıyla karşı karşıyadır.

Bu değişim ve dönüşüm dalgasını toplumun her kesiminde mümkün kılmak, işbirliği ve entegrasyonu sağlamak oldukça önemlidir. Aksi takdirde, doğru işlemeyen ve amaca hizmet etmeyen bir durumla karşı karşıya kalınacaktır. Bu kapsamda da en önemli rollerden biri kamu sektörüne düşmektedir. Kamu sektörünün Toplum 5.0'ın amaç ve araçlarına ne kadar hazır olduğu önemlidir. Kamu sektörü öncelikli olarak hazır hale getirildiğinde toplumsal, siyasi, hukuki ve ekonomik yapıyı da hızla adapte etmek, özel 
sektör ve toplumdaki diğer aktörler için koşulları ve teşvik mekanizmalarını oluşturmak kolay olacaktır. Günümüzde, dünya genelinde kamu sektöründe e-devlet (elektronik devlet) uygulamalarının oldukça yaygın şekilde kullanılmaya başladı̆̆ı görülmektedir. Fakat, her ne kadar bu sistem geliştirilmeye devam etse de halen beklentileri karşılamaktan uzak olduğu söyleyenebilir. Kamu sektöründeki dönüşümün hali hazırdaki durumu böyle iken yapay zeka, robotlar, nesnelerin interneti ve büyük veri analizleri gibi araç ve uygulamaları içinde barındıran Toplum 5.0'a geçişin nasıl, ne ölçüde ve ne kadar hızla olacağı ayrı bir merak konusudur. Akıllı devleti (a-devlet) başarıyla uygulayan toplumların diğer alanlarda da dönüşümü kolayca sağlayabileceği muhtemeldir.

Tüm bu gelişmelerin ışığında, Türkiye'nin durumu ve ileride nasıl şekil alacağı önemlidir. Endüstri 4.0'a daha tam geçemediği görülen Türkiye, Toplum 5.0'ın amaç ve araçlarına adapte olmayı ne ölçüde başarabileceği akıllara gelen ilk sorudur. Toplumsal, ekonomik, hukuki ve siyasi açıdan güçlü ve zayıf yönlerin net olarak ortaya konması gerekmektedir. En önemlisi ise teknolojik olarak ne ölçüde hazır olduğudur. Tüm bunların tespiti yapıldıktan sonra, başta kamu yönetimi ve hizmetlerini şekillendirecek biçimde ulusal bir strateji belirlenmelidir. Toplum 5.0'a uygun şekilde sistemin nasıl dönüştürüleceği noktasında detaylı bir yol haritasına ihtiyaç vardır. Böylece eksikler hızla giderilecek çok boyutlu bir dönüşüm gerçekleştirilebilecektir. Bu dönüşümün de başlangıç noktası kamu sektörü olmalıdır. İşte bu çalışmada da, öncelikle Toplum 5.0 kavramının teorik arka planı detaylı olarak incelenmiş, içeriği, hedefleri ve zayıf yönleri ortaya konmuştur. Sonrasında, Toplum 5.0 çerçevesinde kamu sektörünün nasıl şekil alması gerektiği, dünyadaki genel seyrin ne olduğu ve neler yapılması gerektiği incelenmiştir. Son olarak ise Türkiye'nin toplumsal dönüşümün hangi aşamasında olduğu, eksiklerin ve sorunların kaynaklarının nedeni ve bunların nasıl düzeltilerek Toplum 5.0'a geçişin sağlanabileceği tartışılmıştır. Genel bir değerlendirmeyle beraber çalışma sonlandırılmıştır.

\section{TOPLUM 5.0}

Endüstri 5.0 ismiyle de biline Toplum 5.0, ilk kez Japonya'nın 2015 yılında yayınlanan 5. Bilim ve Teknoloji Temel Planı'nda kullanılmış olan ve sadece endüstri odaklı değil, toplumun her alanındaki değişimi ve dönüşümü ifade eden bir kavramdır (Fujii vd.,
2018: 635). Toplum 5.0 ile hedeflenen "Süper Akıllı Toplumu" gerçekleştirmektir ki, bu da gerçek dünya ile siber alanin entegre edilerek yaratılan ideal toplumu ifade etmektedir (Council for Science, Technology and Innovation, 2015: 13). Bu toplumda; kişilerin ihtiyaç duydukları ürün ve hizmetlere gerekli miktarda ve ihtiyaç duydukları zamanda ulaşabilmesi, herkesin yüksek kalitede hizmet alabilmesi, yaş, cinsiyet, bölge veya dil gibi farklılıkların dikkate alınarak insanların refah içinde yaşayabilmesi hedeflenmektedir (Harayama, 2017:11). Diğer bir ifadeyle, bireysel farklılıklara bakılmaksızın kişilerin gereksinim duyduğu ürün ve hizmetlerin eksiksiz şekilde eşitlikçi bir yaklaşımla karşılanarak insanların rahat ve konforlu hissetmelerini ve sisteme aktif katılımlarını mümkün kılan ve ayrıca kişilerin kendi potansiyellerinin farkına varmalarını sağlayan bir yapılanmayı içermektedir (Fukuyama, 2018: 48).

Dijital teknolojiler temelinde şekillendirilmiş sürdürülebilir bir toplum anlayışını ifade eden Toplum 5.0, insan merkezli bir toplum yapısını oluşturmayı hedeflemektedir. Giderek ilerleyen teknolojinin toplum için bir tehdit değil, toplum ile iş birliği içinde yer aldığ bir yapıyı yaratacak şekilde kurgulanması önceliklidir. Bu bağlamda, teknolojinin doğru bir şekilde yönetilmesi ve yönlendirilmesi, makineler arası iletişimden öte makineler ve insanlar arasındaki etkileşimin sağlanması, Toplum 5.0 ve onun temel felsefesi olan süper akıllı toplumları oluşturmak adına gereklidir (Fukuyama, 2018: 47).

Toplum 5.0 kavramının geniş kitlelere ulaşması Almanya'da 2017 yılında gerçekleşen dünyanın en büyük teknoloji fuarlarından olan CeBIT'de Japonya başbakanı Shinzo Abe'nin yaptığı konuşmada Toplum 5.0 felsefesine değinmesiyle olmuştur. "Her şeyin birbirine bağlı olduğu ve tüm teknolojilerin bütünleştiği bu çă̆ Toplum 5.0 çağıdır" ve "Teknoloji toplumlar tarafından bir tehdit olarak değil, bir yardımcı olarak algılanmalıdır" ifadelerini kullanarak Toplum 5.0'ın içeriğini açıklamıştır (Prime Minister of Japan and His Cabinet, 2021).

Toplum 5.0, avc1/toplayıc1, tarım, endüstri ve bilgiden sonra insan toplumunda beşinci gelişim aşaması olarak ifade edilmektedir (Harayama, 2017: 10). Toplum 5.0 evresine gelinene kadar insanlık tarihi sırasıla; Toplum 1.0, 2.0, 3.0 ve günümüzde geçerli olan Toplum 4.0 olarak adlandırılan evrelere tanık olmuştur (Saracel \& Aksoy, 2020: 27-28; Eren, 2020: 182-184). 
Buna göre Avc1-Toplayıcı Toplum olarak da ifade edilen Toplum 1.0, tabiat ile uyum içinde yaşamış olan avcı ve toplayıcı insan gruplarını; Tarım Toplumu olarak ifade edilen Toplum 2.0 ise tarımsal üretim yapan, organizasyonun arttığ ve ulus inşasına dayalı insan gruplarını temsil etmektedir. Sanayi Toplumu da denen Toplum 3.0 sanayi devrimi yoluyla sanayileşmeyi teşvik eden, seri üretimi olanaklı kılan bir toplumdur. İngiltere'de 1700'lerin ikinci yarısında başlayarak, etkilerini çok uzun süre devam ettirmiştir. Bilgi Toplumu olarak bilinen Toplum 4.0 ise sanal varlıkları bilgi ağları olarak birleştirerek katma değer sağlayan bir toplum yapısını ifade etmektedir. Bilgisayarın ortaya çıkması ve bilişim teknolojilerinin gelişimi Toplum 4.0'1 ortaya çıkarmıştır. Enformasyon temelli olup bilginin elektronik ortamda üretimi, kullanımı ve depolanmasını mümkün kılar hale getirmiştir. Toplumsal gelişimde gelinen beşinci ve son aşama ise Japonya'nın ortaya attığı Toplum 5.0'dır. Toplum 4.0 üzerine kurgulanan ama teknolojinin insanlığın yararına kullanıldığı, sürdürülebilirliğin önceliklendirildiği, tüm alanlarda inovasyon, iş birliği ve dönüşümü hedefleyen, insan merkezli bir topluma karşılık gelmektedir (Fukuyama, 2018: 48; Harayama, 2017: 11; Keidanren, 2018: 5-6).

Toplum 5.0 ile beraber süregelen birçok sosyal soruna yenilikçi, kalıcı ve özellikle de insan odaklı çözümlerin bulunması ve teknolojinin de bu amaçla kullanılması gerektiği vurgulanmaktadır. O yüzden teknolojinin insanlara zarar değil, yarar verecek şekilde kurgulanması gerekmektedir. Robotların ve makinelerin insanlarla iş birliği içerisinde çalışması önemlidir. İdeal bir toplumun gerçekleştirilmesi için nesnelerin interneti, yapay zekâ ve büyük veri gibi teknolojik araçların aktif olarak insan odaklı şekilde kullanımı öne çıkmaktadır. Bu bağlamda, siber alanda biriken bilgilerin ve oluşan büyük verinin yapay zeka tarafından hızla analizi ve alınan sonuçların fiziksel alandaki insanlara geri bildirim olarak sunumu mümkün olacaktır (Japan Cabinet Office, 2020).

Japonya, Ulusal Lisansüstü Politika Araştırmaları Enstitüsü (GRIPS), Bilim, Teknoloji ve İnovasyon Politikası Programı Direktörü Tateo Arimoto ise Toplum 5.0'ın Endüstri 4.0'dan farklı olduğunu ve bu farkın da, Endüstri 4.0'ın bir endüstri devrimi olarak daha çok endüstriyel etkinliklere odaklandığı; Toplum $5.0^{\prime}$ in ise toplumsal refah ve kişilerin mutluluğunu öncelikli kıldığı yorumuyla ifade etmiştir (Kelleli- oğlu, 2018). Japonya İş Federasyonu olan Keidanren (2018:12-15) de Endüstri 4.0 ile Toplum 5.0 arasındaki temel farklılıkları ve Toplum 5.0'in getirmeyi hedeflediklerini şöyle sıralamıştır:

- Verimlilikten öte değerin yaratılmasına odaklanan bir toplum: Endüstri 4.0, seri üretim ve tüketim yoluyla ölçek ve verimlilik peşindedir. Mal ve hizmetler tek tiptir ve standartlaştırılmış süreçler uygulanmaktadır. Toplum 5.0'da ihtiyaçları çeşitlenen insanlar verimliliğe odaklanmaktan kurtulacak ve bireysel ihtiyaçları karşılamaya, sorunları çözmeye ve değer yaratmaya önem vereceklerdir.

- Bireyselliğin baskılanmasından kurtulup herkesin çeşitli yetenekler sergileyebildiği bir toplum: Toplum 3.0 ve $4.0^{\prime}$ da insanların tek tip mal ve hizmetleri kabul etmeleri ve standartlaştırılmış süreçlere uygun olarak tek tip yaşamlar sürmeleri gerekiyordu. Toplum $5.0^{\prime}$ da ise farklı ihtiyaç ve hayal gücüne sahip insanlar, toplumda farklı değerleri sürdürmek için farklı yetenekler kullanacaklardır. İnsanlar, cinsiyet, ırk, milliyet gibi bireyselliklerin baskılanmasından, düşünce ve değerler anlayışıyla yabancılaşmadan uzak yaşayabilecek, öğrenebilecek ve çalışabilecektir.

- Eşitsizlikten kurtulup herkesin her zaman, her yerde fırsatlar elde edebileceği bir toplum: Toplum $4.0^{\prime}$ da zenginlik ve bilginin sinırlı ellerde toplanması eşitsizliği artırmıştır. Toplum 5.0'da ise zenginlik ve bilgi toplum genelinde dağıtılacak ve merkezsizleştirilecek, sosyoekonomik oyuncular rolleri yatay olarak paylaşacaktır. İnsanların eşitsizlikten kurtulması ve herkesin her zaman, her yerde rol oynama firsatları elde etmesi için zenginlik ve bilginin belirli kesimlerde yoğunlaşmaması sağlanacaktır. Dijitalleşmenin eşitsizlik değil, daha çok eşitlik sağlaması yönünde kullanılması hedeflenmektedir.

- Kaygidan kurtulup herkesin gönül rahatlığıyla yaşayabileceği ve zorlukların üstesinden gelebileceği bir toplum: Toplum 4.0'da hızla ve büyük miktarlardaki altyapı bozulmaları, afet ve sel kaynaklı ciddi hasarlar, artan eşitsizlikle bağlantılı olarak kamu güvenliğinin bozulması, terörizm ve siber saldırılar gibi birçok konuda toplumsal kaygılar belirgin şekilde artmaktadır. Toplum 5.0'da yeni, çeşitlendirilmiş ve merkezi olmayan sosyal altyapı, dayanıklılığı 10 kat artıracak ve sürdürülebilir kalkınmayı mümkün kılacaktır. İnsanlar kaygıdan kurtulacak ve güvenlik içinde yaşayacaklardır. Spesifik olarak, fiziksel alanlardaki terör 
ve afetlere ve siber uzaydaki saldırılara karşı dayanıklılık artırılacak, işsizlik ve yoksulluk için güvenlik ağları güçlendirilecektir. Konumdan bağımsız olarak yüksek düzeyde tıbbi bakım erişilebilir olacaktır.

- Kaynak ve çevresel kısitlamalardan kurtulup insanların doğayla uyum içinde yaşayabileceği bir toplum: Toplumlar 3.0 ve $4.0^{\prime}$ da insanlar, yüksek çevresel etkiye ve toplu kaynak tüketimine sahip modellere bağımlıydı. Toplum 5.0'da veri kullanımı enerji verimliliğini ve ademi merkeziyetçiliği artırdığından, geleneksel enerji ağlarına bağlı olmaktan kurtulmak mümkün hale gelmektedir. Aynı zamanda, su temini ve atık yönetimi de hem teknolojik hem de sistemsel bakımdan ilerleyecek ve insanların sürdürülebilir bir hayat yaşamasını sağlayacaktır. Bu da sadece büyük şehirlerde değil, farklı coğrafyalarda doğa ile uyumlu yaşamak için alternatifler yaratacaktır.

Yukarıda bahsi geçen tüm bu hedefler, Endüstri 4.0'ın aksayan yönlerine odaklanarak, sürdürülebilir bir büyüme ve kalkınma modeli gerçekleştirme amacı taşıyan insan odaklı bir toplum yaratma kaygısıyla belirlenmiştir. O yüzden, Endüstri 4.0'ın beraberinde getirdiği nesnelerin interneti, yapay zekâ, sanal gerçeklik, robotik ve büyük veri gibi yeni teknolojilerin endüstriye ve sosyal yaşama yararlı bir şekilde entegre edilmesi önemlidir. Teknolojiyi toplum çıkarına kullanma ve refahı artırma gibi "insan temelli" değişim çabalarına öncelik verilmektedir. Toplum 5.0 ile toplumun her seviyesinde sayısal dönüşüm sağlanarak birçok zorluğun üstesinden gelinmesi hedeflenmektedir (Avşar, 2018: 512). Japonya bu hedefler doğrultusunda üzerinde durulması gereken beş stratejik alan belirlemiştir (Türk Eğitim Derneği, 2020: 4):

- Sağlıklı yaşam süresinin uzatılması

- Hareketlilik (mobility) devriminin gerçekleştirilmesi

- Yeni nesil tedarik zincirinin oluşturulması

- Uygun altyapının geliştirilmesi

- Finansal teknolojinin geliştirilmesi

Bunların yanında, Toplum 5.0'in amacına ulaşması için; kadınların güçlendirilmesi, e-öğrenme sistemleri, erken uyarı sistemleri, akıllı tarım, akıllı gıda, akıllı şehirler ve yenilikçi ekosistem gibi alanlara öncelik verilmesi gerekmektedir (Shiroishi Uchiyama \& Suzuki, 2018: 53-54; Fukuyama, 2018: 49).
Tüm bu stratejik alanlar ekonomik kalkınmayı sağlama ve toplumsal sorunlara çözüm bulma temelinde belirlenmiştir. Böylelikle, hızlı yaşlanan dünya nüfusu için çözümler geliştirmek, sanal dünya ile gerçek dünyanın paralel işler hale getirilmesi, toplumun çıkarları gözetilerek nesnelerin internetinden yararlanılması, doğal afetler ve çevre kirliliği adına çözüm yolları üretilmesi hedeflenmektedir (Büyükgöze \& Dereli, 2019: 2). Bu benzeri hedefler, sürdürülebilir kalkınma politikaları kapsamında değerlendirilmektedir. Zaten Toplum 5.0'1n ana hedef ve bileşenleri Birleşmiş Milletler tarafından kabul edilen 17 "Sürdürülebilir Gelişim Hedefiyle" uyumludur (Atabay, 2021).

Toplum 5.0'ın temelinde toplumsal gelişimin tarih içerisinde gösterdiği değişim yanında endüstri devriminin gösterdiği değişim de belirleyici olmuştur. 18.yüzyılın ortalarında başlayan endüstriyel değişimler hali hazırda devam etmektedir. Ekonomik ve toplumsal hayatı etkileyen bu değişimler Endüstri 1.0'dan 4.0'a olmak üzere dört evrede ele alınmaktadır. Endüstri 1.0 olarak bilinen ilk sanayi devrimi, 18. yüzyılda İngiltere'de ortaya çıan ve su, rüzgar ve buhar gününün makinelerde ve taşımacılıkta kullanılmasını imkan veren makineleşmenin (mekanik üretimin) başladığ1 dönemdir. Tarım toplumundan sanayi toplumuma dönüşüm başlamıştır (Okan Gökten, 2018: 882; Saracel \& Aksoy, 2020: 27). İkinci sanayi devrimi ise Endüstri 2.0'dır. 19. yüzyılda elektriğin keşfedilmesi sayesinde elektrik gücü sanayide kullanılmaya başlanmış ve seri üretime geçilmiştir (Turan, 2020: 58). Ayrıca, dünya çapında demir-çelik üretimi hızla artmış ve köprüler, demiryolları ve gökdelenler için malzemeler temin edilir hale gelmiştir (Saracel \& Aksoy, 2020: 27). Üçüncü sanayi devrimi olan Endüstri 3.0 dijital devrim olarak da adlandırılmaktadır. Bilgi teknolojileri üretimde kullanılmaya başlamış, dijitalleşme, programlanabilir makineler, internet ve elektronik alt yapı bu dönemin temel belirleyicileri olmuştur. Üretim sürecinde otomasyona geçiş sağlanmıştır (Turan, 2020: 58; Akpınar, 2018: 6). Dünyanın önemli bir bölümünün halen içerisinde olduğu Endüstri 4.0 ise akıllı fabrikaların temelde şekillendirdiği devrimdir. Bu fabrikalarda bilişim teknolojileriyle endüstri bir araya getirilerek insanlardan büyük ölçüde bağımsız üretim yapılabilmektedir. Maliyet, zaman ve kalite açısından fayda sağlayan bu durum siber-fiziksel sistemleri, nesnelerin interneti, hizmetlerin interneti, akıllı ürünler ve bulut teknolojileri gibi unsurları üretim ağlarına sokmuştur (Saracel \& Aksoy, 2020: 28). Kendi aralarında iletişim sağla- 
yabilen siber-fiziksel sistemlerle insan gücü önemini yitirmeye başlamıştır (Dombrowski \& Wagner, 2014: 101).

Her geçen gün hayata geçirilmeye çalışılan yeni endüstri devrimi ise Endüstri 5.0 ya da en çok bilinen ismiyle Toplum 5.0'dır. Teknolojinin insanlık için tehdit değil, yardımcı olarak algılanmasının öne çıkarıldı ̆̆ bu devrimde sanayiden çok toplum önceliklidir. Teknoloji odaklı bir anlayışına dayanan Endüstri 4.0' dan farklı olarak Toplum 5.0, yaşam kalitesini, sosyal sorumluluğu ve sürdürülebilirliği iyileştirmede Endüstri 4.0 'ın yarattığ 1 sonuçlardan ve teknolojiden daha fazla faydalanarak insanların refah düzeyinin artmasina önem vermektedir (Ferreira \& Serpa, 2018: 27). Yapay zeka, nesnelerin interneti, büyük veri analizleri gibi araç ve yöntemlerle yaşlanan nüfus, çevre kirliliği, iklim değişikliği, gıda güvenliği, toplumsal eşitsizlikler, afet, terörizm gibi sorunlara yenilikçi çözümler bulunması hedeflenmektedir. Ayrıca, Endüstri 5.0'da "robot" kelimesi de sadece süregelen görevleri gerçekleştiren programlanabilir bir makine olma anlamın1 yitireceği belirli konularda insana benzer ideal bir arkadaşa dönüşeceği öngörülmektedir. Yapay zekaya sahip bu robotların güvenlik anlamında bir risk taş1mayacak şekilde insana dost ve yardımcı bir makine haline getirileceği iddia edilmektedir.

Toplum 5.0'in her ne kadar ekonomik ve toplumsal açıdan pek çok yarar sağlayacağı öngörülse de getirebileceği sakıncalar ve zorluklar da yok değildir. Yap1lan bazı araştırmalar neticesinde karşı karşıya kalınabilecek riskler şöyle sıralanmıştır (Haaga, 2019: 13-14 Saracel \& Aksoy, 2020: 29):

- Teknolojik gelişme ile toplum arasındaki farklılıkların yanında toplum ve iş piyasasındaki değişime bağlı olarak karşı karşıya kalınabilecek hukuki sorunlar

- Toplumsal değişimlere bağlı olarak yaşlı nüfus ve genç nüfus sayılarındaki orantısız değişim.

- Yazılım entegrasyonu ve yükseltmesinde karşı karşıya kalınan problemler

- Teknolojinin yanlış amaçlar doğrultusunda kullanılmasi

- Bilişim teknolojilerine ve elektriğe bağımlılığın artmas1

- Paydaşlar ve üst kademe üyelerin değişmeye istekli olmamas1
- Gerçek zamanlı süreçler ve uygulamalara bağlı olarak yaşanabilecek senkronizasyon sıkıntısı

- Güvenlik, özellikle de siber güvenlik konusundaki kaygilar

Tüm bunların yanında, nesnelerin dijitalleşmesindeki bilimsel boşluklar, kalifiye personel eksikliği, sosyo-politik önyargılar ve toplumsal direnç gibi başlıklar da Toplum 5.0'a geçiş sürecinde karşı karşıya kalınabilecek diğer sorun alanlarıdır (Atabay, 2021). Bunun yanında, Toplum 5.0'ın yaratacağı en büyük toplumsal sorunun istihdamla ilgili olduğu ifade edilebilir. Yapay zeka ve robotlar birçok sektörde istihdamını azaltma yönünde önemli bir riski beraberinde getirmektedir. Birçok meslek anlamını yitirecek, bazı sektörlerde neredeyse hiç insana ihtiyaç kalmayacaktır. Ayrıca, bu durum eğitim sisteminin de yeniden kurgulanmasını gerektirecek, yeni meslek ve iş alanları karşımıza çıkacaktır. Hatalı üretimi sıfıra indireceği, hızı ve verimi arttıracağı öngörülen bu yapı da ortaya çıkacak istihdam sorunu gibi temel sorunların nasıl önleneceği oldukça önem taşımaktadır.

Söz konusu zorlukları ve riskleri ortadan kaldırmanın yolu ise Japon İş Dünyası Federasyonu olan Keidanren tarafından şöyle sıralanmıştır (Keidanren, 2016: 14):

- Kamu kurumları tarafından ulusal stratejilerin yapılması ve devlet teşvik/tanıtım sisteminin entegrasyonu gereklidir.

- Yasal düzenlemeler ileri teknolojilere uygun olarak güncellenmelidir.

- Önemli kişisel verilerin kullanılması ile siber güvenlik, biyo, nano, robot gibi teknolojilere yönelik ciddi altyapı hazırlıkları ve Ar-Ge faaliyetleri gerçekleştirilmelidir.

- İnsan kaynağını güçlendirmek ve geliştirmek adına bilgi teknolojileri okuryazarlığı, mevcut insan gücünün ileri düzey sayısal becerilerle donatılması gibi eğitim reformları yapılmalıdır. Toplumun ileri teknolojiler ile entegre olmasının gerçekleştirilmesi büyük önem taşımaktadır.

- Toplum 5.0, toplumdaki tüm aktörleri menfaat temelinde bir araya getirmektedir. Bu anlamda, tüm vatandaşların ortaya çıkan bu ekonomik ve toplumsal düzene aktif katılımı sağlanmalıdır. 
Söz konusu sorunların doğru çözüm öneriyle erken şekilde tespiti ve gerekli tedbirlerin alınması Toplum 5.0'in toplumsal problemleri çözmek ve teknolojiyi insanların menfaatlerine hizmet edecek şekilde kullanılmasını, teknolojiyi toplumla bütünleştirip toplumun refah düzeyini yükseltmek suretiyle yeni değerler yaratmasını ve insan merkezli bir toplum meydana getirme hedefine ulaşmasını fazlasıyla sağlayacağı söylenebilir. Toplum 5.0, dijital dönüşümün toplumsal problemleri çözmek ve değer yaratmak adına çeşitli insanların hayal gücü ve yaratıcılığıyla birleştiği bir yaratıcı toplum olacaktır. Toplum 5.0'da insanlar sadece kendileri için değil, aynı zamanda doğa ve teknoloji için de sürdürülebilir kalkınmayı sağlamak adına onlarla ortak yaşamanın yollarını aramada hayal gücünü kullanacaklardır.

Toplum 5.0'a geçiş sürecinde kamu hizmetlerinin nasıl bir şekil alacağı ise ayrı bir sorun alanıdır. İnsan odaklı bir toplum yaratma hayali kamu hizmetlerine nasıl yansıyacak ve arzulanan teknolojik dönüşüm kamu hizmetlerine nasıl uyarlanacak sorularına yanit bulmak gerekmektedir. Aldığımız kamusal hizmetler bizim yaşam kalitemizi etkilediği ve sürdürülebilirliği sağlamada belirleyici olduğundan ileride bu hizmetlerin alacağı şekil önemlidir. Bu bağlamda, eğitim, sağlık, savunma, ulaşım gibi temel kamu hizmetlerini Toplum 5.0'ın amaç ve araçları doğrultusunda dönüştürmede devletlere önemli görevler düşmektedir.

\section{TOPLUM 5.0 VE KAMU HIZMETI ANLAYIŞI}

Yaşanan teknolojik ilerlemelerle beraber, tüm dünyada devletlerin hizmet anlayışını değişmeye ve kamusal hizmetler yeniden yapılandırılmaya başlamıştır. Devletler hizmetleri vatandaşlara giderek dijital ortamda sunmaktadır. Bu bağlamda, günümüzde e-devlet uygulamaları hız kazanmıştır. Teknolojiden mümkün olduğunca çok yararlanarak devletler kaliteli, etkin ve hızlı şekilde kamusal hizmetleri sunmaya, vatandaş odaklı hizmet anlayışını gerçekleştirmeye çalışmaktadırlar. Artan talep ve çeşitlenen ihtiyaçlar doğrultusunda teknoloji merkezli kamusal hizmetler giderek hayat bulmaktadır.

İlk olarak kamu kurumlarında yazışmaları hızlandırmak ve evrak takibini kolaylaştırmak için kurulan e-devlet uygulamaları, zamanla sadece devletten devlete uygulamalar değil, devletten vatandaşa uygulamalar şeklini almıştır. Böylece, farklı kurumlar vatandaşlara sunduğu bazı hizmetleri (borç ödeme, başvuru takibi, sağlık sonucu izleme gibi) elektronik ortama taşımış ve vatandaşların hizmetlere erişimini kolaylaştırmıştır. Sonraları farklı kurumların sunduğu bu hizmetler, tek bir platformda toplanarak vatandaşa sunulur hale gelmiştir. Günümüzde, birçok ülkede kamusal hizmetlerin önemli bir kısmı dijital platforma taşınarak e-devlet gibi tek bir kapı üzerinden entegre biçimde vatandaşların kullanımına açılmış durumdadır. Vatandaşlar tek bir link üzerinden kullanıcı adı ve şifreleriyle farklı kamu kurumlarında alabilecekleri hizmetlere ulaşmaktadır. Bu kapsamda vergi borç veya cezalarını ödeme, hastane ve aşı randevusu alma, sağlık sonuçlarını takip etme, kimlik veya pasaport gibi bazı değerli evrakların başvuru veya takibini yapma, dava süreçlerini ve sonuçlarını izleme gibi işlemleri gerçekleştirebilmektedirler.

Toplum 5.0'a geçişin gündeme geldiği bu dönemde hizmetlerin ve nesnelerin interneti, yapa zeka, büyü veri analizleri, insanlarla işbirliği içinde çalışan robotlar gibi teknolojik araçların kamu hizmetlerinde de yer bulacağı aşikardır. Çok eski bir geçmişi olmayan ve aslında yeni yeni yaygınlık ve uygulama alanı kazanan e-devlet yerini a-devlete (akıllı devlete) bırakacak gibi gözükmektedir. A-devlet kavramı, aslında e-devleti dışlamayan, onu da içine alan daha şemsiye bir kavramdır. Teknolojilerin yoğunluğu ve türlerindeki artışla beraber, kamusal hizmet sunum biçimi e-devletin ilerisine taşınmaktadır. Özellikle, akıllı nesnelerin ortaya çıkışı, var olan nesnelerin internetinin gelişmesi, açık erişimli standartlar ve ara yüzlerin yaygınlaşması, siber güvenliğin iyileşmesi, yapay zeka ve blockchain uygulamalarının ilerlemesi gibi olgular devletlerin a-devlete dönüşümünü zorlayan öncülerdendir (Lucke, 2016: 20). Böylece, devletler de ortaya çıkan ekonomik ve toplumsal sorunları giderme konusunda daha fazla hassasiyet göstererek bilişim teknolojilerini ve iletişim ağlarını sistemlerine daha çok entegre edecek şekilde yenilikçi politikalar ve iş modelleri geliştirdikleri, hizmetleri de vatandaş odaklı olmaktan öte insan odaklı bir yapıya büründürmeyi amaçladıkları bir yapı kurma çabasındadırlar. İşte, a-devlet de tam bu yapı üzerine oturan bir modeldir. Doğal afetler, salgın hastalıklar ve iklim değişikliği gibi yaşamlarımızın ciddi şekilde tehdit altında olduğu bir dünyada devletler de sürdürülebilirliğe ve yaşam kalitesini arttırmaya daha çok odaklanarak teknolojiyi sunduğu hizmetlerde insan odaklı olarak kurgulamaktadırlar. Bilgi ve iletişim teknolojilerinde- 
ki ilerlemeleri vatandaşlarının ama bunun da ötesinde insanlığın yararına olacak şekilde kamusal hizmetlere uyarlamakta, BM'nin 17 temel sürdürülebilirlik hedefine hizmet eden yaşanabilir ülke ve dünya anlayışını benimseme ve yerleştirme çabasındadırlar. A-devlet uygulamalarının da bu amaca hizmet etmek için oluşturulmuş, Toplum 5.0 anlayışına dayanan bir kamu hizmeti sunum modeli olduğunu söylemek yanlış olmayacaktır. Giderek devletteki dijital değişim a-devlet ile kurumsal bir nitelik kazanmaktadır.

Devletin dijital dönüşümünü evrelere ayıracak olursak, başlangıcının 1980'lere dayandığını söyleyebiliriz. Devlet 1.0 olarak bilinen Eski Model ya da diğer ismiyle Bilgilendirme Modeli evresi, bilişim teknolo-

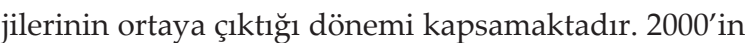
başına kadar devam eden dönemde bilişim teknolojilerinden nasıl yararlanılabileceği tam olarak anlaşılmamış, kurumlar arası entegrasyon ve paylaşım sınırlı kalmıştır. Teknolojik savurganlık yüksek düzeyde seyrederken bu teknolojilerin yönetimde tam kullanımı mümkün olmamış, vatandaşların ve özel sektörün süreçlere katılımı sağlanamamış, merkezi hükümetin egemenliği devam etmiştir. Devlet 2.0 olarak bilinen mevcut model ya da diğer isimleriyle e-Devlet, e-Dönüşüm, Açık Hükümet Modeli evresi 2000-2013 yılları arasında yaşanmıştır. Ama halen dünyada pek çok ülkede kullanımı ve egemenliği devam etmektedir. Çok sayıda devletin e-devlet dönemini yaşadığını söylemek yanlış olmayacaktır. Daha vatandaş odaklı, paylaşım ve entegrasyonun kurumlar arasında gerçekleştiği bir dönemdir. Kurumdan kuruma ve kurumdan vatandaşa veri ve hizmet sunumu elektronik ortamda mümkün hale gelmiştir. Devletin dijital dönüşümünde gelinen son evre ise, Devlet 3.0 evresidir. Gelişmekte Olan Model ya da Akıllı Hükümet Modeli olarak bu evre, 2014 sonrasında hayatımıza girmiş ve sonrasında Toplum 5.0 anlayışı tarafından şekillendirilmiştir. Özellikle sürdürülebilirliği temel alarak sosyal, politik, çevresel ve finansal kurumlarla entegre hareket eden, nesnelerin interneti, yapay zeka, robotlar ve siber güvenlik üzerine odaklanarak daha hızlı gerçek zamanlı, çevik hizmet sunumu ve yazılımı geliştirme ve daha kapsaml, hedefli ve kişiselleştirilmiş veriler sunmayı hedefleyen bir devlet modelini temsil etmektedir. Günümüzdeki birçok devletin henüz adım atamadığı ve atanların ise yolun oldukça başında olduğu akıllı devlet modelinde hizmetlerin yaşam kalitesini en üst düzeye çıkaracak şekilde oluşturulması ve dijitalleştirilmesi önemlidir (Petrov, 2014: 6-11).
Kamusal yönetiminin ve kamusal hizmetlerin evrildiği bu dönemde Toplum 5.0 anlayışı çerçevesinde nasıl bir dönüşüme gidilmesi gerektiği sorusunun cevabı kafalarda tam netleşmiş değildir. Yukarıda da ifade ettiğimiz gibi öncelikli konu, kamusal hizmetlerin giderek dijitalleşmesi gereğidir. Tabi, bu dijitalleşme sürdürülebilirliğe ve yaşam kalitesine hizmet edecek şekilde olmalıdır. İkinci olarak ise kamu yönetiminde dijital inovasyon yapılırken, ademi merkeziyetin oluşturulması, kaynakların ve otoritenin merkezden bölgelere aktarılması ve böylece bölgelerin özerk bir şekilde kalkınması sağlanmalıdır. Bölgelerin gücündeki artış ise hem hedeflenen dönüşümü kolaylaştıracak hem de refah artışına daha çok hizmet edecektir.

Yerelleşen ve dijitalleşen kamu hizmetlerinin en tipik örnekleri son yıllarda karşımıza çıkan Akıllı Şehir uygulamalarında görülmektedir. Akıllı şehirlerin, insan müdahalesi gerektirmeksizin birbiri ile iletişime geçen sensörlerin, süreç yönetimi, akıllı ulaşım ve lojistik teknolojileri gibi uygulamaların yer aldığı yaşam kalitesine ve şehirlerin sürdürülebilirliğine hizmet eden insan odaklı kurgulanmış yaşam alaları olduğu ifade edilebilir. Almanya'nın bazı bölgeleri ile İspanya, Hollanda, ABD, Çek Cumhuriyeti ve Singapur'da akıllı şehir uygulamalarının örneklerine rastlanmaktadır. Şehirler sensörlerle donatılarak enerji takibi, atık su yönetimi, trafik yoğunluğu, dolan çöp kutularının anlık tespiti, elektrik ve su dağıtım kanallarındaki sızıntıların sensörler ile tespiti, park kullanımları gibi fark1 alanlarda bilgiler hızlıca elde edilmektedir. Şehirde ulaşım ağları ve yeşil binalar başta olmak üzere pek çok noktada akıllı sistemler oluşturularak tasarruf ve hizmet kalitesinde artış sağlamaktadır (Foresti et al., 2019: 3; Saracel \& Aksoy, 2020: 33; Lom, Pribyl \& Svitek, 2016: 5).

Akıllı şehir konseptinde toplum hayatını düzenleyici kamusal hizmetlerde yapısal dönüşüm hedeflenmektedir. Şehirlerin yönetiminden eğitime, sağlı̆̆a, kamu güvenliğine, ulaşıma ve başka çok sayıda kamusal hizmette akıllı, birbirine bağlı ve verimli bir yapının oluşturulması gerekmektedir (Akbaş \& Öztuna, 2019: 424). Böylece, kent sakinlerinin kamu hizmetlerinden eşit bir biçimde yararlanması mümkün hale gelirken kamu kaynaklarının etkin ve verimli kullanımı sağlanacaktır. Bu bakımdan birçok ülkede e-belediyecilik uygulamalarının yanında sensörlerle elde edilen bilgiler akıllı teknolojilerin aracılığıyla şehirdeki trafik, enerji, park gibi sorunların çözümünde ve hizmetlerin 
sunumunda kullanımının yolları aranmaktadır (Köseoğlu \& Demirci, 2018: 49-54). Söz konusu sistemlerin oluşturulabilmesi, Toplum 5.0'la amaçlanan sürdürülebilirlik için teknolojiye hizmet edecek şekilde şehirlerin toplumsal, kültürel ve ekonomik gelişimlerine büyük katkı sağlayacaktır. İnsanların yaşamları daha kolay ve kaliteli hale gelecektir. Bunu sağlamada, kent düzeyindeki tüm aktörlerin işbirliği, iletişim ve entegre bir şekilde hareket etmesi önemlidir.

Toplum 5.0 projesi kapsaminda Japonya'da 157 bölgede kamu-özel-akademi ortaklığında toplam 229 adet akıllı şehir projesi uygulamaya konmuştur. Örneğin, toplu taşıma seçeneğinin zayıf ama araç yoğunluğunun fazla olduğu Maebashi şehrinde nüfusun yaklaş1k \%30'u 65 yaş ve üzerindedir ve bireysel araç kullanmaları zordur. Söz konusu inisiyatif kapsamında sürücüsüz toplu taşıma araçlarının diğer akıllı şehir ağına entegre edilmesiyle Maebashi ulaşım problemi büyük ölçüde rahatlamıştır (Deguchi, 2020).

Akıllı şehirler kapsamında gerçekleştirilmeye çalışılan bu tür uygulamaların ulusal çaptaki tüm kamu hizmetleri için de tasarlanması gerekmektedir. Bu kapsamda, bazı öneri ve çalışmaların yapıldığı görülmektedir. Sağlık sektöründeki gelişmeler öne çımaktadır. Özellikle, giyilebilir teknolojiler ve yeni nesil yüksek hızlı iletişim ağları sayesinde uzaktan tıbbi bakım hizmetleri gelişimi özellikle yaşlıların sik sık hastaneye gitme gereksinimlerini ortadan kaldırarak kendi sağlıklarını kontrol altında tutmaları ve tıbbi bakım tesislerinde yapay zeka ve robotların kullanımı yoluyla insanların bağımsızlığını destekleme mümkün hale gelmektedir. Giyilebilir teknoloji ürünlerinde bulunan sensörler sayesinde, kişinin sağlığına ilişkin bazı bilgiler (kalori, nabız, tansiyon gibi) telefon gibi elektronik cihazlara yansımakta, ağın bir diğer paydaşı olan sağlık kuruluşu ya da doktor da bu veriyi görebilmektedir. Bu sayede uzaktan bakım hizmetleri artmakta, hastalar kendi tedavilerinde aktif rol oynamakta, erken teşhis kolaylaşmakta, sağlık kuruluşlarına gelişi hafifletmektedir (Sertaç Arı, 2021: 466; The Government of Japan, 2019; Kent, 2019).

Sağlıkta olduğu gibi eğitimin de Toplum 5.0'ın gerekleri ve gereçleriyle dönüşümü kaçınılmazdır. Eğitimi ihtiyaç ve gelişmelere göre güncellemeden diğer alanlarda ilerleme beklemek nafile bir çaba olacaktır. Temel kamu hizmet alanlarından biri olan eğitimin teknolojik ilerlemelere hılı adaptasyonu ve sürdürülebilir yaşam tarzı vizyonuyla kurgulanması Toplum 5.0'a geçişte önemlidir. O yüzden, robotik sistemler, nesnelerin interneti, büyük veri teknolojisi ve yapay zeka gibi öncelikli alanlara göre eğitim sisteminin güncellenmesi ve nitelikli işgücü gereksiniminin karşılanması gerekmektedir (Auffray, Balling \& Zanetti, 2016: 7).

Toplum 5.0’la beraber ciddi dönüşüm sağlayacağ öngörülen bir diğer sektör, ulaşımdır. Köy ve kasaba gibi nüfusun oldukça az olduğu bölgelerden hastane veya AVM gibi merkezlerde bulunan yerlere seyahat etmek, birçok insan için toplu taşımanın yetersizliğinden dolayı oldukça zordur. O yüzden, otonom/sürücüsüz araçlar veya teslimat dronları ihtiyaç ve talepleri karşılamada yeni alternatifler olacaktır. Ulaşım da bu bağlamda giderek bir sorun alanı olmaktan çıkacaktır. Bununla beraber, ulaşım ağlarını rahatlatacak bir diğer uygulama sensörlerin kullanımı olacaktır. Sensörler aracılığıyla yol, köprü, tünel veya baraj gibi arızalanan yerlerin erken bir aşamada tespiti yapılabilecektir. Böylelikle, kaza ihtimali düşerken güvenlik ve verimlilik artacaktır (The Government of Japan, 2019). Ulaşım hizmetleri çerçevesinde self-servis havaalanları, mobil cihaz destekli araçlar da gelişimini sürdürecektir (Eggers \& Macmillian, 2015: 9).

Ekonomi ve finansal yönetim de Toplum 5.0'la beraber gelişen teknolojik araçlarla giderek kabuk değiştirmektedir. Özellikle, insanların yaşam kalitesini iyileştiren uygulamalar hayata geçmektedir. Örneğin, parayı yurtiçi ve özellikle de yurtdışına havale etmek hem pahalı hem de zaman alan bir işlemdir. Blockchain teknolojisi, küresel ticari işlemlerde güvenliği sağlamakta, zaman ve maliyet avantajı sunmaktadır (The Government of Japan, 2019). Ayrıca, dijital dönüşüm ödeme, finansman, sigorta ve varlık oluşturma gibi birçok kişiye özel finansal hizmetleri kullanıma sunacaktır. Kişiye özel gelişmiş akıllı varlık yönetimi ve sigorta optimizasyonu ortaya çıkabilecek riskleri en aza indirirken istikrarlı varlık oluşumunu kolaylaştıracaktır (Sertaç Arı, 2021: 467).

Afetlerin önlenmesi ve azaltılmasında Toplum 5.0'ın geliştirdiği ve geliştirmeye devam ettiği teknolojik araçların risklerin azaltılmasında oldukça yararlı olacağ1 beklenmektedir. Tahliye merkezlerinden, nesnelerin interneti araçlarından ve sosyal medyadan hasar ve kurtarma hakkında veri toplayarak ve bunları hem kamu hem de özel sektörde bölgeler ve kurumsal sınırlar arasında paylaşarak afet durumunda hızlı müdahaleyi kolaylaştırmak için afet bilgi işbirliği sistemleri 
kurulacaktır. Ayrıca, altyapının eskimesini önlemek adına günlük bakım ve verimli önlemler yoluyla afetlerin azaltılması için dijital teknolojiler kullanılacaktır. Su ve kanalizasyon altyapısının bakımı ve hızlı restorasyonu, afet ve kaza durumlarında su temininin devam etmesini sağlayacaktır. Afetlerde sürdürülebilir sistemler kurmak için enerjinin yerelleştirmesi teşvik edilecektir. Toplum 5.0, özellikle afetlere karşı hassas altyapıya sahip alanlarda yaşam standartlarını ve dayanıklılığı iyileştirmeye destek olacaktır (Keidanren, 2018: 16). Afet koşullarına ve insanların sığınaklara güvenli bir şekilde transferi sensörler ve sürücüsüz araçlar yardımıyla yol hasarı bilgileriyle gerçekleştirilebilecek, her kişiye bireysel akıllı telefon ve diğer cihazlar aracılığıyla barınak ve yardım hakkında bilgi verilir hale gelecektir. Mağdurlar durumda olanlar kurtarma robotları vb. sayesinde anında keşfedilecek ve afetten zarar gören binalardan hızlı bir şekilde kurtarılabilecektir. Drone'lar ve otonom sürüşlü araçlar aracılığıyla yardım malzemeleri hızlıca ve sağlıklı şekilde teslim edilebilecektir (Saif Obaid Alhefeiti, 2018: 11-12). Bu durum devletin böyle durumlarda hizmet yapma kabiliyeti, hızı ve niteliğini iyileştirecektir.

Toplum 5.0'ın topluma sunulan tüm bu kamusal hiz-

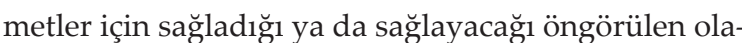
naklar dışında bazı riskleri de beraberinde getirmiyor değildir. Örneğin, insan çalışanların yerini giderek robotların alması, gelirin ve vergi tabanının daralmasına, kamu harcamalarının da artarak kamu mali dengesinin bozulmasına yol açması muhtemeldir. Robotların işçilerin yerini almasıyla hükümetlerin işsizlere yönelik hastalık sigortası ve işsizlik yardımları gibi sosyal destek uygulamalarını hayata geçirmeleri gerekecektir (Bootle, 2019: 190-191). Ayrıca, yeni iş alanlarına yönelik olarak işsiz kalanları eğitmek amacıyla da ek sosyal destek programları gerekli olacaktır (Mazur, 2019: 292; Turan, 2020: 64). Bununla beraber, robotlar işçilerin yerini alırken onlar gibi stopaj ya da harcamalar üzerinden alınan vergiler açısından vergi rejimlerine tabi olmayacaklardır. Böylece artan robot kullanımının hem o ülkenin toplam vergi matrahını hem de ücret üzerinden ve KDV ve ÖTV gibi harcamalar üzerinden alınan vergi gelirlerini azaltması beklenmektedir (Yıldız, 2019: 312). Her ne kadar bu vergilerdeki düşüşün artan Kurumlar Vergisi tahsilatıyla dengeleneceği öngörülse de sermaye kazanca ve ticari kazanca amortisman, istisna ve teşvik gibi araçlar sayesinde daha düşük vergi yükü yüklenmesi muhtemeldir. Robotların artan oranda emeğin yerine konmalarıyla beraber büyüyen işsizlik ve kamu kaynaklarının yetersizliği sorunu robotlardan vergi alınması zorunlu hale getirecektir ki zaten robot vergisi de geleceğin en tartışmalı konularından biri olacağa benzemektedir (Turan, 2020: 65). Elektronik kişi olarak kendilerine ayrı bir kişi sıfatı yüklenecek olan robotlar vergi yükümlüsü olabilecek ve neden olacakları iktisadi eşitsizlikleri ortadan kaldırmak için vergilendirme aracı olarak kullanılabilecektir. Böylece firmalar daha az vergi vermek için değil daha üretken olacakları zaman robotları kullanmayı tercih edeceklerdir. $\mathrm{Bu}$ durum işsizliğin hızla artmasını yavaşlatacak ve ekonomik eşitsizlik azalacaktır. Robot vergisine karşı çıkanlar ise böyle bir verginin robotlaşmayla sağlanacak verimlilik artışına sekte vuracağını ve küresel rekabette geride kalınacağını ifade etmektedirler.

Toplum 5.0'ın riskleri sadece robotlarla sinırlı değildir. Toplumsal ve siyasi altyapının yeterli olmaması, politika yapıcıların farkındalığının düşük olması, hukuki zeminin bu teknolojik değişime uygun olmaması, kamu sektöründeki teknolojik altyapı eksikliklerinin varlığı, bilgi teknolojileri temelinde kamu sektöründe yaşanacak dönüşüme uyum sağlayabilecek insan kaynağının sınırlılığı, toplumsal direnç ve etik sorunlar gibi pek çok problem geçilmeye başlanan bu toplumsal dönüşümde, kamu sektörünü beklemektedir. Söz konusu bu engeller nasıl aşılabileceği sorusunun ise son günlerde oldukça üzerinde durulmaktadır. Bu bağlamda ortaya çıkan öneriler şöyle sıralanabilir (Türk Eğitim Derneği, 2020: 6-7; İ-scoop, 2018; Sertaç Ar1, 2021: 468):

- Toplumun tüm aktörlerini (Özel sektör, üniversiteler, STK'lar vb.) sürece dahil edecek şekilde bir ulusal planın ve stratejinin oluşturulması, bu plan dahilindeki tüm uyguların üstten alta kadar hızlıca özümsenip hayata geçirilmesi,

- Tüm kamuda bilgi teknoloji temelli dönüşüm için devlet tarafından gerekli altyapı eksiklerinin giderilmesi,

- Kurumlar bazında teşvik ve uyum sistemlerinin oluşturulması (Siber güvenlik, yapay zeka, robotlar, nanoteknoloji, biyoteknoloji gibi teknolojilerin kamu sektöründe kullanımının teşvik edilmesi, bilim ve teknolojideki inovasyonla ilgili çevrenin iyileştirilmesi)

- Hukuk sistemindeki Toplum 5.0'ın amaç ve araçları kapsamında gerekli revizyonların yapılması, sürdürülebilirlik ve yaşam kalitesi önceliklerinin göz ardı 
edilmemesi, teknolojik değişime göre düzenlemelerin yapılması, verilerin kullanımı ve uygulamasını teşvik etmek için kurallar geliştirilmesi, siber güvenliğe yönelik yasal düzenlemelerin oluşturulması,

- Tüm vatandaşların değişen koşullar karşısında aktif ve donanımlı hale gelmesi için eğitimde gerekli reformların gerçekleştirilmesi (yaratıcılı̆̆ın teşvik edilmesi, bilgi teknolojileri okuryazarlığını ilk ve orta öğretim seviyelerinden itibaren geliştirmek ve yaşam boyu eğitimin teşvik edilmesi), siber güvenlik, veri bilimi ve uluslararası standardizasyon için personel temininin güvence altına alınması ve teşvik edilmesi

- Ulusal çaptaki bu değişim karşısında toplumsal mutabakat oluşturulması için gerekli çabanın gösterilmesi ve süreçte karşı karşıya kalınabilecek etik sorunların ele alınması önerilmektedir.

Kamu sektöründe Toplum 5.0'in sunduğu yenilikler ışığındaki dönüşümün örneklerine bazı ülkelerde rastlanmaya başlamıştır. Özellikle yapay zeka bu anlamda, önemli bir yer tutacak gibi görülmektedir. Japonya'da, kamu sektöründe yapay zeka uygulamalarını giderek yaygınlaştırdığı bilinmektedir. Toplum 5.0'ın tasarımcısı olan ülke olarak Japonya'nın bu anlamda öncü olması diğer ülkelere örnek teşkil etmesi adına da önem arz etmektedir. Japonya'da kamu sektörünün gelecekte yapay zeka ve büyük veri uygulamaları olmadan işlemeyeceğine kesin gözüyle bakılmaktadır. Bu şekilde, kişiselleştirilmiş kamu hizmetinin etkin şekilde sağlanacağı da öngörülmektedir (The Government of Japan, 2019). Bunun yanında, Birleşik Krallık Hükümeti tarafından 2018 yılında kurulan Dijital ve Yaratıcı Endüstriler Bakanlığı'nın bünyesinde gerçekleştirilen çalışmalarda da kamu politikalarında yapay zekanın üst düzey kullanımına geçildiği belirtilmektedir (Government of UK, 2018).

Sonuç olarak, tüm dünyada Toplum 5.0'ın önemli bir ekonomik ve toplumsal dönüşümü öngördügü bu süreçte en önemli dönüşüm ayağının kamusal alanda gerçekleşmesi gerektiğini söylemek yanlış olmayacaktır. Nihayetinde özellikle gelişmiş ülkelerde bu yöndeki uygulama örneklerine rastlanmaya başlamıştır. Günümüzde hem merkezî hem de yerel yönetimlerin sundukları hizmetleri ve yönetim sistemlerini sürdürülebilir yaşam vurgusuyla dijitalleşmeye dayalı olarak yeniden inşa etmeleri önemlidir (Sertaç Arı, 2021: 467). Yönetimler görevlerinin çoğunu dijitalleştirerek ve çeşitli aktörler arasında hızlı bir şekilde veri payla- şarak, daha yaratıcı kamu hizmetleri sunar hale gelmelidir. Bu bağlamda, tüm düzeylerde kamu sektörü için süreçleri iyi işler hale getirecek ve hizmet kalitesini yükseltecek yeniliklerin tespit edilmesi, bunların hayata geçirilmesi için gerekli fiziki ve beşerî altyapının oluşturulması, devam eden süreçlerin optimizasyonu ve ana hedef olarak kamu hizmetlerinde dönüşümün sağlanması gerekmektedir (Tinholt et al., 2017: 7-8). Tüm dünyada kamu sektöründeki bu dönüşümü gerçekleştirebilmesi, ekonomik büyüme ve kalkınma için bir gereklilik haline gelmektedir. Küresel rekabet adına da önemli olan bu durum için toplumların ne kadar hazır olduğu ve ne ölçüde bu değişimi gerçekleştirebilecekleri ayrı bir tartışma konusudur. Hızla kalkınma ve büyüme hedefiyle küresel ortamda avantaj elde etme çabasında bir ülke olarak Türkiye için de bunun nasıl gerçekleştirileceği ve ne durumda olduğunu analiz etmek gerekmektedir.

\section{TOPLUM 5.0 KAPSAMINDA TÜRKIYYE'DE KAMU HIZMETLERININ DURUMU}

Tüm dünyayı giderek etkisi altına alan dijital dönüşüm, Türkiye'de de ciddi şekilde hissedilmektedir. Özellikle, son dönemde yaşadığımız koronavirüs pandemisiyle beraber de dijital teknolojiler hayatımızda daha çok yer alma eğilimindedir. Teknoloji kullanımının ve ihtiyacının giderek artması ise onların gelişim hızının artmasına neden olmaktadır. İşte, Türkiye de tam bu noktada başta kamu sektörü olmak üzere her alanda dijital dönüşümün günün gereklerine göre sağlanması çabalarını sürdürmektedir. Bu bağlamda, Toplum 5.0 evresine geçiş sürecinin kamu sektöründen başlatarak gerçekleştirme çabaları görülmektedir. Dönüşümün başlangıcı kamu yönetimi ve hizmetleri olmalıdır, çünkü toplumun diğer alanlarındaki dönüşüm ancak devlet yapısındaki dönüşümle beraber hızlı bir şekilde gerçekleştirilebilecektir.

Türkiye'de kamu sektöründeki dijital dönüşüm çalışmaları, 1990'lı yıllardan itibaren kamu örgütlerinin bilgi ve belge paylaşımıyla beraber başlamıştır. Böylece elektronik devletin temelleri atılmıştır. Bu doğrultudaki ilk politik adımın ise 1993 yılında Dünya Bankası'yla ortak hazırlanan Bilişim ve Ekonomik Modernizasyon Raporu olmuştur. Sonrasında, Kamu Net Teknik Kurulu kurularak kamu sektöründe teknolojik dönüşümün alt yapısının oluşturulması noktasında önemli bir adım atılmıştır. 2001 yılında ise e-Avrupa+ Eylem Planını temel alınarak Türkiye'de 
e-devlet çalışmaları hızlandırılmıştır. Kurumların sürece hızlı bir şekilde entegrasyonu sağlanırken, sistemin eksikleri ve aksayan yönleri hızla giderilmeye çalışılmıştır. Şu anda Türkiye'de e-devlet uygulaması üzerinden pek çok kamu hizmeti tek kapı üzerinden yürütülebilmektedir. Kişiler, kimlik numaraları ve şifreleriyle hastane randevusu, pasaport randevusu gibi işlemler yanında, davalarını takip edebilmekte, vergi borçlarını ödeyebilmekte ve pek çok bilgiyi sorgulayabilmektedirler.

Türkiye e-devleti kullanım ve uygulama konusunda önemli bir aşama kaydetmiş olmakla beraber, sürdürülebilirlik ve yaşam kalitesi amaçlarını öne çıkaran Toplum 5.0 ile beraber kamu sektörü hizla kabuk değiştirmektedir. Artık, e-devletten öte gidilerek akıllı devlet olarak ifade edilen a-devlet uygulamaları öne çıkmaktadır. Daha önce de ifade ettiğimiz üzere, akıllı devlet, dijital dönüşümün araçlarındaki ilerlemelerle e-devletin daha ileri bir versiyonudur. Türkiye'de de bu anlamda geçişi hızlandırma noktasında çalışmalar yapıldığı görülmektedir. A-devletin alt yapısı olarak Türkiye'de Elektronik Kamu Bilgi Yönetim Sistemi (KAYSİS) kurulmuştur. Kurum www.kaysis.gov. tr internet sayfasında "KAYSIS, kamu kurumlarının teşkilat yapısından, sunulan hizmetlere, hizmetlerde kullanılan belgelerden, belgelerde bulunan bilgilere kadar kamu yönetiminde yer alan unsurların mevzuat dayanaklariyla birlikte tespit edilerek elektronik ortamda tanımlandığı, geliştirilen e-Devlet uygulamalarının birbirine tek merkezden entegre edilerek a-devlete (Akıllı Devlet) geçilmesini sağlayacak temel bir bilgi sistemidir" olarak tanımlanmıştır (kaysis.gov. tr, 2019). KAYSİS ile kamu kurum ve kuruluşlarının sunduğu hizmetlerin hukuki dayanakları görülebilmekte, vatandaşlara yapılan anketlerle kamu hizmetlerinden memnuniyetleri ölçülerek geri bildirimde bulunulmakta ve vatandaşların hizmetleri alabilecekleri kurumlar ile hizmet alabilmek için istenilen bilgiler edinebilmektedir (Avaner \& Fedai, 2019: 163).

Türkiye' de kamuda dijital dönüşümün ve akıllı devlet uygulamalarına doğru geçişin en önemli adımı Dijital Dönüşüm Ofisi'nin kurulmasıyla olmuştur. Türkiye'de 2018 yılında Cumhurbaşkanlığı Hükümet Sistemi'yle geçilen yeni sistemde bazı ofisler oluşturulmuştur. Bunlardan biri de Dijital Dönüşüm Ofisidir. Bu ofis, devleti akıllı devlete dönüştürme noktasında koordinasyon görevini üstlenmektedir. Bürokrasiyi azaltma hedefiyle Dijital Türkiye projesini de yöne- ten ofis, teknolojiyi sadece tüketen değil, üreten bir Türkiye olmak hedefiyle Ulusal Yapay Zekâ Stratejisi yol haritasını hazırlamakta ve siber güvenliği sağlama konusunda önemli çalışmalar yürütmektedir. Ayrıca, yerli ve milli teknolojilerin başta kamu sektörü olmak üzere tüm sektörlerde yaygınlaştırılması çalışmalarını yürütmektedir. KAYSİS de Dijital Dönüşüm Ofisi'nin koordinatörlügüünü üstlendiği bir platformdur.

Gelinen bu aşamada hem kamu sektöründeki dijital dönüşüm en üst noktaya taşınmaya hem de devlet anlayışı tüm dünyada olduğu gibi koordinatör devlet olarak değiştirilmeye çalışılmaktadır. Akıllı devlet ile yapay zeka ve robotik sistemlerin kamu hizmetlerinin sunumunda etkin hale getirilmesi amaçlanmakta, devletin ise bu noktada düzenleyici ve denetleyici devlet olarak görev alması hedeflenmektedir. Akıllı devlet, aynı zamanda koordinatör devlet anlayış1nın bir tamamlayıcısıdır. Bununla beraber, devletin akıllı olabilmesinin koşullarından biri de hem kamu kurumları hem de diğer toplumsal aktörler arasında uyumun sağlanabilmesidir (Avaner \& Fedai, 2019: 158). O yüzden, devlet koordinasyon ve düzenleme rolünü üstlenmektedir. Devletin müdahaleci olma görevini bıraktırma konusundaki çalışmalar 1980'lere dayanmakta ve günümüzde farklı gerekçelerle devam ettirilmektedir. OECD tarafından da devlet düzenleyici devlet olarak yoluna devam etmesi, ekonomik ve toplumsal hayatı piyasa bakışı altında düzenleyerek ve yapacağı bütün örgütlenmeler ile çıkaracağı mevzuatı piyasaya yük getirmeyecek şekilde oluşturması gerektiği ifade edilmiştir (OECD, 2002: 160). Kamu sektöründeki tüm dijitalleşme çalışmaları bu anlayış çerçevesinde şekillendirilmeye çalışılmakta, akıllı devlet uygulamaları hızla hayata geçirilerek Toplum 5.0'ın öngördüğü sürdürülebilir bir ekonomik büyüme ve kişilerin yaşam kalitesinde iyileşme sağlanmaya çalışılmaktadır.

Türkiye' de akıllı devlet uygulaması olarak TÜBİTAK öncülüğündeki Bilişim ve Bilgi Güvenliği İleri Teknolojiler Araştırma Merkezi (BİLGEM) tarafından desteklenen akıllı devlet uygulamalarından olan bulut bilişim teknolojisi de, güvenli depo uygulaması ile ön plana çıkmaktadır. Bununla beraber, TÜBİTAK'ın öncülüğünde geliştirme aşamasında olan başka projeler de bulunmaktadır. Oldukça yeni bir süreç olmasından dolayı bu çalışmaların sonuçları da yeni yeni ortaya çıkmaktadır (TÜBİTAK, 2016).

Türkiye' de dijital dönüşüm ve akıllı devlet uygulama- 
larının en net örnekleri belediyeler tarafından oluşturulan akıllı kent modellerinde görülmektedir. Bu modellerin en önemli özelliği sürdürülebilirliğin sağlanmasına hizmet etmesidir. Bu bağlamda, Çevre ve Şehircilik Bakanlığı tarafından oluşturulan 2020-2023 Ulusal Akıllı Şehirler Stratejisi ve Eylem Planı sayesinde yapay zeka uygulamalarının şehircilikte kullanımı öngörülmüş̧ür. Bina yapımında, afet tespitinde, ulaşım sistemlerinin düzenlemesinde, çevre güvenliği alanında, otomasyonda ve benzeri akıllı sistemlerin geliştirilmesinde ve uygulanmasında yapay zeka kullanımının mümkün olduğu belirtilmiştir (T.C. Çevre ve Şehircilik Bakanlığı, 2019).

Eğitim alanında ise dijitalleşmenin ve akıllı sistemlerin en önemli örneklerine yükseköğretim kurumlarında daha çok rastlanmaktadır. Bu bağlamda, "yaşam boyu öğrenme" yaklaşımına dayanan uzaktan eğitim uygulamaları öne çıkmaktadır. Bunun dışında, konuya ilişkin diğer bir örnek ise Bornova Belediyesi tarafından gerçekleştirilen "dijital sınıf" uygulaması ile ilçede eğitim gören yaklaşık 55.000 ilköğretim ve ortaöğretim öğrencisinin yararlanacağı bir sistemin yaratılması adımıdır (T.C. Bornova Belediyesi, 2019). Sağlık sektöründe ise robotik cerrahiler, 3 boyutlu yazıcılar ve kişiselleştirilmiş sağlık uygulamaları yaygınlaştırılmaya çalışılmaktadır. Türkiye'nin sağlık hizmetleri konusunda dijitalleşme bakımından önemli ilerleme sağladığı söylenebilir. Devlet destekli ar-ge çalışmalarına da bu alanda öncelik verilmektedir.

Sosyal hizmetlerin toplumsal dönüşüm ve entegrasyon süreçlerini sağlık bir şekilde gerçekleştirmede en önemli hizmet alanlarından birini oluşturduğu ifade edilebilir. O yüzden, endüstriyel ve toplumsal devrim aşamalarını hızlı bir şekilde tamamlamaya ihtiyacı olan Türkiye'nin bu alanda kat ettiği mesafe önemlidir. Toplum 5.0'la uyumlu biçimde sosyal hizmetlerin giderek kişiselleştirilmesi ve dezavantajlı gruplara hizmet edecek yapay zeka uygulamalarının geliştirilmesi yönünde çabalar sürmektedir. Böylece, yaşam kalitesini iyileştirme amacına ulaşılmak istenmektedir.

En temel kamu hizmetlerinden biri olan savunma konusunda ise Türkiye'nin Toplum 5.0'a doğru önemli adımlar attığı ifade edilebilir. Siber güvenlik çalışmaları, insansız hava araçları ve yüz tarama yazılımlarının kullanımına geçildiği görülmektedir. Fakat, burada dışa bağımlılığımızın daha çok azaltılması, savunma gibi kritik bir hizmet alanı için bir gerekliliktir.
Milli üretime giderek önem verildiği bilinmekle beraber çalışmaların yoğunlaştırılması yararlı olacaktır.

Ulaştırma alanında ise ciddi bir mesafe kat edildiği söylenebilir. İnternet kullanımının yoğun olduğu bu sektörde, özellikle coğrafi bilgi sistemlerinde yapay zeka uygulamaları ve 5G altyapısına geçiş yönünde önemli adımlar atıldığ 1 ifade edilebilir. Toplum 5.0'ın kullanımını yaygınlaştırmayı hedeflediği sensör sistemleri için de çalışmaların yapıldı̆̆ı bilinmektedir. $\mathrm{Bu}$ uygulamalar gerçekleştirilebildiği takdirde ulaşım hizmetleri bakımından Türkiye'nin nitelik, hız ve verimlilik gibi başlıklarda önemli başarı sağlayacağı muhakkaktır.

Farklı sektörlerde gerçekleştirilen veya gerçekleştirilmek istenen tüm bu değişimlerin kilit noktalarından biri ekonominin büyüklüğü ve istikrarı yanında ekonomik yapının Toplum 5.0 uygulamalarına ne kadar entegre olduğuyla ilgilidir. Devletin öncülüğünde gerçekleştirilecek dijital ve sosyo-ekonomik dönüşüm büyük bir ekonomik gücü gerekli kılmaktadır. İstikrarlı bir şekilde devam ettirilmesi gereken altyapı çalışmaları için istikrarlı bir ekonomik sistem önemlidir. Fakat, bunun yanında ekonomik ve mali yapının dijitalleşme ve sürdürülebilirlik yönündeki durumu etkilidir. Türkiye'de kamu mali yönetim süreçlerinin dijitalleşmesi uygulamalarının başında bütünleşik mali yönetim bilgi sistemi gelmektedir. Bu sistem yönetim ve bütçe kararlarını, güvenden doğan sorumluluklar1 ve finansal raporların ve ifadelerin hazırlanmasını desteklemek için finansal işlemlerde bilgi ve iletişim teknolojisinin kullanılmasını ifade etmektedir (Uçma Uysal \& Aldemir, 2018: 505). Ayrıca, bütünleşik mali yönetim bilgi sistemi, tek bir kurumun yetki ve sorumluluğu altındaki merkezi bir sistemi değil, kurumların kendi yetki ve görev tanımları çerçevesinde işlettikleri bilişim sistemlerinin, birbirleri ile entegre edilmesi sonrasında oluşacak yapıyı göstermektedir (BKMYBS, 2017: 18). Bunun yanında, blok zinciri temelli muhasebe sistemi, kripto para analizi gibi birçok teknolojik uygulamanın ekonomik ve mali sistem içerisine yerleştirildiği görülmektedir. Türkiye'de yapay zeka uygulamalarının da finansal alanda geliştirme çabaları mevcuttur.

Tüm bu dönüşüm süreçlerin sağlıklı bir şekilde yürütülebilmesinin ve sürdürülebilirliğinin sağlanması için hukuki yapının da bu doğrultuda şekillendirilmesi gerekmektedir. Çünkü dijitalleşmenin getirdikleri her alandaki yapılanmayı ve işleyişi değiştirdiği 
için yasal süreçler de bu doğrultuda güncellenmelidir. Türkiye' de büyük veri, siber güvenlik ve internet teknolojinin etki alanları dikkate alınarak mevzuatta güncellemeler yapılmaya başlamıştır. Ayrıca, yapay zekanın mevzuata kapsamlı bir şekilde dahil edilmesi, sanal mahkemelerin ve sanal hapishanelerin kurulmasının alt yapısı hazırlanmaktadır (Tamer \& Övgün, 2020: 792-793; Eggers \& Macmillian, 2015: 50).

Türkiye'de başta kamusal olmak üzere tüm hizmet türlerinde dijital dönüşüm hızlı bir şekilde gerçekleştirilmeye çalışılmaktadır. Toplum 5.0'ın gerektirdiklerini anlama ve uygulama yönünde çalışmalar ve hazırlıklar başlatılmıştır. Fakat, burada cevaplanması gereken en önemli soru, Türkiye'nin özel ya da kamu sektöründe bütünüyle bu endüstriyel ve toplumsal değişimin hangi aşamasında olduğudur. Bu sorunun cevabı, atılması gereken adımların ortaya konması bakımından da önemlidir. Bu kapsamda, TÜBİTAK tarafından Haziran 2016' da Türkiye sanayisinin dijital olgunluk seviyesini tespit etmek için Ar-Ge desteği almış 1.000 adet özel sektör kuruluşuyla "Yeni Sanayi Devrimi: Akıllı Üretim Sistemlerine Yönelik Kilit ve Öncü Teknolojiler Önceliklendirme" isminde bir anket çalışması yapılmıştır. Anket sonucunda işletmelerin Ar-Ge ve akıllı üretime yönelik ilgi ve entegrasyon seviyeleri ölçülmüştür. Sonuçlar, Türkiye sanayisinin dijital olgunluk seviyesinin Endüstri 2.0 ile Endüstri 3.0 arasında olduğunu göstermektedir (TÜBİTAK, 2016). TÜBİTAK'ın anket çalışmasının yanı sıra Bilim, Sanayi ve Teknoloji Bakanlığı tarafından Türkiye Verimlilik Gelişim Haritası Projesi kapsamında 2016 yılında yaklaşık 10.000 işletmeyle, işletmelerin Endüstri 4.0'a ilişkin farkındalık seviyelerini ölçmek için bir araştırma gerçekleştirilmiştir. Araştırma sonuçları, Türkiye'deki işletmeler arasında büyük veri ve nesnelerin interneti teknolojilerinin bilinirliğinin düşük olduğunu göstermektedir (Bilim, Sanayi ve Teknoloji Bakanlığı, 2019: 70). 2018 yılında ise İstanbul Sanayi Odası (İSO) tarafından “Türkiye'nin 500 Büyük Sanayi Kuruluşu 2018” araştırması yapılmıştır. Araştırma sonuçlarına göre, Türkiye'de 2018 yılında bir önceki yıla göre orta-düşük teknoloji yoğunluklu sanayilerin payı azalırken (\%39,9- \%35,0) orta-yüksek ve yüksek teknoloji yoğunluklu sanayiler grubunun payı artmıştır (\%20,2-\%22,2). Ayrıca yüksek teknoloji yoğunluklu sanayiler grubunun payı 2017 yılında \%3,6 iken 2018 yılında \%5,3 olmuştur (İSO, 2020).

Yukarıda bahsettiğimiz tüm bu araştırmaların hepsi
Türkiye sanayisinin dijital olgunluk seviyesini ölçmeye yöneliktir. Fakat bizim çalışmamızın da konusunu oluşturan Türkiye'de kamu sektörünün dijital dönüşüm bakımından geldiği noktaya yönelik yapılan kapsamlı bir araştırmaya rastlanmamaktadır. Bu noktada karşımıza sadece 2018 yılının Mayıs ayında Avrupa Birliği (AB) tarafından yayınlanan Türkiye'de e-Devlet Raporu karşımıza çıkmaktadır. Her bir ülke için hazırlanan raporların Türkiye bölümünde, Türk kamu yönetiminde dijitalleşme altyapısına yönelik kısa vadede etkili bir değişim yaşanmadığı ifade edilmektedir. Raporda Türkiye'ye ilişkin mevcut siyasi ve ekonomik yapıya yönelik bilgilere yer verildikten sonra internet kullanımının yanı sıra, vatandaşların internete erişim düzeyleri ve kamu kurumlarına web tabanından form gönderim oranı $\mathrm{AB}$ ülkeleri ile k1yaslanmaktadır. Buna göre Türkiye'nin $\mathrm{AB}$ ülkelerine dair rakamlara, 2016 yılından itibaren yaklaştığ 1 ifade edilebilir. Ayrıca raporda, e-devlet hizmetlerinde \%73 oranında artış yaşandığına yer verilmiştir (Avaner \& Fedai, 2019: 167).

Türkiye'nin Toplum 5.0'a adaptasyonunun önünde birtakım engeller bulunmaktadır. Bu engellerin başında dijital dönüşüm için gerekli olan teknolojik altyapı ve bu teknolojik dönüşüme uyum sağlayabilecek nitelikli iş gücü eksikliği gelmektedir. Mevcut işgücünün dijital yetkinliklerinin geliştirilmesi, bilgi ve bilinç düzeyinin artırılması gerekmektedir. Ayrıca, yapay zekâ, büyük veri, otonom robotlar, bulut bilişim gibi dijital çağın öncü teknolojilerinin geliştirilmesi ve bunların tüm süreçlere uygulanması konusunda devlet tarafından gerekli altyapı eksikler giderilmeli ve teşvikler sağlanmalıdır. Bununla beraber, beşerî sermayeyi güçlendirmeye yönelik yapılacak yatırımlar ve güçlü bir Ar-Ge altyapısı ile dijital teknolojilerin yurtiçinde üretilmesi ve bu kapsamda dışa bağıml1lığın azaltılması dijital dönüşümdeki sürdürülebilir gelişim için önemlidir (Türk Eğitim Derneği, 2020: 10). Bunun yanında, eğitimde reform yapılarak sistemin dijital okuryazarlığı arttırma, kişilerin yetenek ve ilgilerini merkeze alacak şekilde kişisel gelişimi, yaratıcılığı ve uzmanlaşmayı geliştirecek bir sistemin hayata geçirilmesi gerekmektedir. Sürecin başarısı eğitim sisteminin günün ihtiyaç ve gelişmelerine uygun şekilde iyileştirilmesi, toplumun bilgi, yetenek ve farkındalıklarının geliştirilmesine bağlıdır. Aksi takdirde, sürdürülebilir bir ekonomik büyüme ve yaşam kalitesi merkezli bir dijital dönüşümü sağlıklı şekilde gerçekleştirmek mümkün olmayacaktır. Tüm bunla- 
rın yanında, siyasi ve hukuki altyapı da Toplum 5.0'in hedef ve uygulama araçlarına göre güncellenmelidir. Dijitalleşme konusunda oldukça istekli ve yoğun çaba içerisinde olan Türkiye'nin özellikle kamu sektöründen başlayarak ciddi bir dönüşüm hareketi başlatmalı, toplumu da bu yönde hazırlamalıdır.

\section{DEĞERLENDİRME VE SONUÇ}

Dünyada karşı karşıya kalınan ekonomik ve toplumsal sorunlar büyürken teknoloji hizla ilerlemektedir. Ortaya çıkan bu durum, teknolojinin sorunları tetikleyen mi yoksa çözen mi olacağı sorusunu gündeme getirmiştir. Bu tartışmalar 2017 yılında Japonya tarafından Toplum 5.0 olarak nitelendirilen yeni bir toplumsal değişim sürecini başlatmıştır. Teknolojik gelişmeleri insan odaklı şekilde kurgulayarak sürdürülebilir kalkınmayı sağlama ve toplumsal sorunları çözerek yaşam kalitesini yükseltme hedefi taşıyan Toplum 5.0 felsefesi inovatif bir toplum yaratma anlayışı taşımaktadır. Nesnelerin interneti, yapay zeka, robot teknolojileri, büyük veri analizleri gibi ileri düzey teknolojik araçlarla yaşlanan dünya nüfusuna karşı çözümler geliştirme, sanal dünya ile gerçek dünyanın birlikte çalışmasını sağlama, çevre kirliliği ve doğal afetler için çözüm yolları üretme gibi amaçların gerçekleştirilmesi hedeflenmektedir.

Dünyadaki bu hızlı teknolojik ilerleme karşısında devletler de gerekli hazırlıkları yapma mecburiyetine girmişlerdir. Dijital dönüşüm kamu yönetiminde ve kamu hizmetlerinde de değişimi mecbur kılmaktadır. Hizmetlerin giderek kişiselleştirilmesi, farklılaştırılması, hızlı, kaliteli ve erişiminin kolay olması önemlidir. Teknolojinin sağladığı imkanlar insanların hizmeti bekleme veya aynı standartta hizmet alma gibi durumları kabul etmez hale getirmiştir. Dünya örneklerini ve uygulamalarını gördüklerinde benzerlerine sahip olma konusunda israrcı olmaktadırlar. Bir ülkede ulaşım sektöründe insansız hava araçlarının yük veya insan taşımasında giderek kullanılır hale gelmesi başka devletlerin de bunu uygulama konusunda gerekli çalışmaları yapmaya mecbur kılmaktadır. Benzer şekilde, kamu hizmetlerinde yapay zekanın ve bu bağlamda akıllı devlet uygulamalarının giderek yaygınlaştığ Japonya, başka devletlere de örnek olmaktadır. Türkiye de dahil birçok devlet kamu yönetim anlayışında ve eğitimden sosyal hizmetlere kadar her kamu hizmetinde bu dijital dönüşümü gerçekleştirme gayretindedir. Özellikle, yerel bazdaki kamusal hizmetlere ilişkin dijitalleşme çalışmaları daha yoğun olarak görülmektedir. Bu bağlamda, özellikle akıllı şehirler projeleri dikkat çekmektedir. Yerel ölçekte planlama yapmak ve uygulamaya koymak daha kolay olduğundan yerel örneklere daha çok rastlanmaktadır. Bu durumun bazı artı ve eksi tarafları bulunmaktadır. Hizmeti gerçekleştirmek daha kolay olmakla birlikte, yönetimler arası imkanlar ve vizyon açısından farklılıklar olması bütüncül bir değişimi zorlaştırmaktadır. Fakat hızlı uygulama ve hızlı sonuç olup vatandaşların en çok kullandığı ve varlığını hissettiği hizmetlerde bunun uygulanması başarı şansını arttırmaktadır.

Türkiye'deki süreçte benzer yapıdadır. Yerel bazda akıllı şehir örneklerine ve dijital dönüşüm uygulamalarına daha çok rastlanmaktadır. Büyükşehir belediyelerinin bu anlamda bir adım daha önde olduğu ifade edilebilir. Merkezi yönetim kapsamında ise özellikle kurulan Dijital Dönüşüm Ofisi aracılığıyla sürecin tek bir elden planlanmaya çalışıldığı, uygulamalar arasındaki entegrasyonun sağlandığı ve sistemleri geliştirme çabalarının yürütüldüğü söylenebilir. Türkiye özellikle e-devlet uygulamaları bakımından epey ileriye gitmiş durumdadır. Neredeyse sisteme entegre olmamış hiçbir merkezi kurum kalmadığı gibi çok sayıda hizmet giderek sistem içerisine alınmakta ve hizmetlere bir şifreyle tek kapıdan erişilebilmektedir. Benzer şekilde, yerel yönetimler de vergi ve su borcu ödeme gibi tahsilat işlemlerini, imar başvurusu gibi bir takım başvuru işlemlerini elektronik ortamda vatandaşlarına sunmaktadır. Türkiye e-devlet anlayışı çerçevesinde hızla dönüşüm gerçekleştirme çabasındayken Toplum 5.0'ın akıllı devlet ve bu kapsamdaki yapay zeka, robotlar ve büyük veri analizleri gibi uygulamalarına adaptasyonu gündeme gelmektedir. Tüm dünyayı etkisi altına alan bu dönüşüme Türkiye'nin ne kadar başarabileceği merak konusudur. Öncelikle, politika ve toplumsal anlamda bir değişimi her ülkenin olduğu gibi ülkemizin de gerçekleştirmesine ihtiyaç vardır. Artan çevresel, toplumsal ve ekonomik sorunlar karşısında küresel gereksinim ve politikalara uygun hareket etmek gerekmektedir. Cinsiyet, ırk, milliyet gibi farklılıklara göre değil, bireysel ihtiyaç ve taleplerdeki farklılıklara göre bir politika oluşturulmalıdır. Hizmetlerin kişiselleştirilmesine ve mikro ölçeğe indirilmesine ihtiyaç vardır. Teknolojik entegrasyon tek tip ama hizmetler çeşitli olmalıdır. Ayrıca, tüm bu değişim sürecinde ekonomik büyüme ve kalkınma hedefinin sürdürülebilirlik anlayışı çerçevesinde şekillendirilmesi, insanların yaşam kalitelerini iyileştiren her bir unsurun günün imkan ve gereksi- 
nimlerine göre güncelleme yapılması gerekmektedir. Çünkü gelişen altyapı eksikleri, deprem ve sellerin neden olduğu ciddi hasar, artan eşitsizlikle bağlantılı olarak kamu güvenliğinin bozulması, terörizm ve diğer krizlere ilişkin artan sosyal kaygı, bozulan ekolojik denge ile siber saldırıların neden olduğu hasarlar gibi toplumsal huzursuzluğa neden olan faktörler kald1rılmalı ya da en aza indirgenmelidir. Bunun için de teknolojik imkanlar önemli bir alan yaratmaktadır. Ülkemizin bu anlamda gelişmeleri iyi takip etmeli, durum tespiti yapmalı ve gerekli hazırlıkları hayata geçirmelidir.

Tüm bu süreç içerisinde ise Türkiye'de önce Toplum 5.0'a geçişin önündeki engeller iyi analiz edilmelidir. Öncelikle, teknolojik altyapı eksiklerin giderilmesine ihtiyaç vardır. 5G teknolojisi, yapay zeka uygulamaları ve büyük veri analizleri gibi araçların giderek kullanılmaya başlandığı bir dünyada Türkiye de AR-GE çalışmalarına hız vermelidir. Bununla beraber, eksik olunan tek konu fiziki yatırımlar değil, beşeri sermayenin güçlendirilmesine de ihtiyaç vardır. Türkiye'nin dijital dönüşüme ve paradigma değişimine uyum sağlayacak nitelik eleman gereksinimi bulunmaktadır. $\mathrm{Bu}$ konu, kamu sektörü için daha elzemdir. Mevcut personelin hem bilgi ve yetileri hem de adaptasyon konusundaki isteksizlikleri dönüşümün önündeki önemli bir engel oluşturmaktadır. O yüzden, sonraki süreçte hizmet içi eğitimlerle mevcut personelin iyileştirilmesi, alınacak personel de ise ilgili beceri ve bilginin aranması gerekmektedir.

Sözü edilen bütün bu eksiklerin giderilmesinde öncelikle yapılması gereken şey ise politik, hukuki ve toplumsal altyapının hazırlanmasıdır. Siyasi plan ve programlar oluşturulup yapılacaklara yönelik yol haritaları çıkarılmadan, hukuki anlamda karşı karşıya kalınabilecek sorunlara karşı nasıl çözümler geliştirileceği tespit edilmeden ve toplumsal adaptasyon sağlanmadan fizik ve beşeri yatırımların yapılması yetersiz olacaktır. Bu anlamda siber güvenlik, kişisel verilerin korunması gibi başlıklarda hukuki boşluklar doldurulmalı, gerekli yaptırımlar hayata geçirilmelidir. Çünkü Türkiye'de kişisel verilerin gizliliği sorunu hali hazırda tam olarak çözülebilmiş değildir. Politika yapıcılar açısından ise Toplum 5.0'ın hedeflediği insan odaklı, yaşam kalitesini iyileştirme ve sürdürülebilir bir ekonomik büyümeyi sağlama yaklaşımını her bir alanda nasıl hayata geçirileceği noktasında çalışmalara hız verilmelidir. Eğitim, sağlık, ulaşım, turizm gibi her bir alanda devlet gerekli tedbir ve teşvik mekanizmalarını oluşturmalıdır. Kişiselleştirilmiş hizmetlerle ortaya çıkan salgın, afet, terörizm, kriz gibi çok sayıda önemli toplumsal sorunlar yanında günlük toplumsal ihtiyaçların hızlı ve etkin şekilde giderilmesine öncelik verilmelidir. Bu bağlamda, dijital teknolojilerin entegrasyonu önemlidir. Tabi bunların da ötesinde, toplum bu dönüşme hazır hale getirilmelidir. Özellikle de, zihinsel dönüşüm sağlanmalı, dijitalleşmenin önemi ve gerekliliği topluma iyi bir şekilde anlatılarak hem farkındalığı arttırılmalı hem de bilgi ve yeterliliklerini iyileştirme çalışması yapılmalıdır. Bu anlamda, devletin yapacağı seminerler, halka açık söyleşi ve bilgilendirme toplantıları, kamu spotları, kurslar ve eğitim olanakları ile eğitim sisteminde gerçekleştireceği yenilikler etkili yöntemlerdir. Toplumun bu konuda istekli ve hazır hale getirmek, Toplum 5.0'a geçişi daha da kolaylaştıracağı gibi, sürdürülebilirlik odaklı yaşam tarzı ve yaşam kalitesi için bir gerekliliktir.

\section{KAYNAKÇA}

AKBAŞ, İ. \& ÖZTUNA, B. (2019) Akıllı Kent Ekseninde Üretimin Yeniden Tanımlanması. 10. Uluslararası Sivil Toplum Kuruluşları Kongresi, Bandırma, 1-3 Kasım 2019, 419-431.

AKPINAR, M. (2018). Endüstri 4.0'dan Toplum 5.0'a Geçerken Să̆llk Bilişiminin Geleceği. Sağlik-Der Bilişim Komisyonu https://docplayer.biz. tr/105279557-Endustri-4-0-dan-toplum-5-0-gecerken-saglik-bilisiminin-gelecegi.html (Erişim Tarihi: 02.08.2021)

ATABAY, S. (2021), Endüstri 4.0'dan Toplum 5.0'a. Hürriyet, 5 Nisan, https://www.hurriyet.com.tr/egitim/endustri-4-0dan-toplum-5-0a-41780170 (Erişim Tarihi: 21.08.2021)

AUFFRAY, C., BALLING, R. \& ZANETTI, G. (2016), Making Sense of Big Data in Health Research: Towards an EU Action Plan. Genome Medicine, $8(71), 1-13$

AVANER, T. \& FEDAİ, R. (2019). Türk Kamu Yönetiminde Ofis Sistemi: E-Devlet Uygulamalarından Dijital Dönüşüm Ofisine. Amme İdaresi Dergisi, 52(2), Haziran, 149-172.

AVŞAR, İ. İ. (2018). Endüstri 4.0 Yorumu: Toplum 5.0. Al-Farabi 2nd International Congress on Social Sciences: The Book of Full Text, 6-8 Nisan 2018, 510-514.

BILLIM, SANAYİ VE TEKNOLOJİ BAKANLIĞI. (2019). Türkiye'nin Sanayi Devimi. "Dijital Türkiye” Yol haritası. https://www.gmka.gov.tr/ dokumanlar/yayinlar/2023 Dijital-Turkiye-Yol-Haritasi.pdf (Erişim Tarihi: 24.08.2021).

BKMYBS, (2017). Bütünleşik Kamu Mali Yönetim Bilişim Sistemi Politika Belgesi ve Eylem Planı, http://www.gsb.gov.tr/public/edit/files/strateji/ButunlesikKamuMaliYonetimBilisimSistemi.pdf (Erişim Tarihi: 14.08.2021)

BOOTLE, R. (2019). The AI Economy: Work, Wealth and Welfare in the Age of the Robot. Boston, MA/USA: Nicholas Brealey Publishing. 
BÜYÜKGÖZE, S. \& DERELİ, E. (2019). Toplum 5.0 ve Dijital Sağlık. IV. Uluslararası Bilimsel ve Mesleki Çallşmalar Kongresi-Fen ve Sağllk Tam Metin Bildiri Kitabı, 7-10 Kasım 2019, 1-5.

COUNCIL FOR SCIENCE, TECHNOLOGY AND INNOVATION (2015). Report on The 5th Science and Technology Basic Plan. Cabinet Office, Government of Japan https://www8.cao.go.jp/cstp/kihonkeikaku/5basicplan en.pdf (Erişim Tarihi: 14.08.2021)

DEGUCHI, A. (2020). Society 5.0 and its Application to American Smart Cities. https://www.americancityandcounty.com/2020/06/10/society-5-0and-its-application-to-american-smart-cities/ (Erișim Tarihi: 01.08.2021).

DOMBROWSKI, U. \& WAGNER, T. (2014). Mental Strain as Field of Action in the 4th Industrial Revolution. Procedia CIRP, 17, 100-105.

EGGERS, W. D. \& MACMILLAN, P. (2015). Kamu 2020: Kamunun Geleceğine Yolculuk. İstanbul: Deloitte

ELEKTRONIK KAMU BILGI YÖNETIM SISTEMI (KAYSIS) (2021). Kaysis Hakkında. https://www.kaysis.gov.tr/Kaysis_Hakkinda (Erişim Tarihi: 24.08.2021).

EREN, Z. (2020). Toplum 5.0 ve Dijital Dünyada Toplumsal Dönüşüm ve Eğitim 5.0. Akçay, D. \& Efe, E. (Editörler), Dijital Dönüşüm ve Süreçler içinde, İstanbul: İstanbul Gelişim Üniversitesi Yayınları, No: 74, ISBN: 978 605-4827-69-5, 169-206.

FERREIRA, C.M. \& SERPA, S. (2018). Society 5.0 and Social Development: Contributions to a Discussion. Management and Organizational Studies, 5(4), 26-31. 6

FORESTI, R., ROSSI, S., MAGNANI, M., LO BIANCO, C. G. \& DELMONTO, N. (2019). Smart Society and Artificial Intelligence: Big Data Scheduling and the Global Standard Method Applied to Smart Maintenance, Engineering, 1-12.

FUJII, T., GUO, T. \& KAMOSHIDA, A. (2018). A Consideration of Service Strategy of Japanese Electric Manufacturers to Realize Super Smart Society (Society 5.0). International Conference on Knowledge Management in Organizations, Springer, Cham., 634-645.

FUKUYAMA, M. (2018). Society 5.0: Aiming for a New Human-Centered Society. Japan Spotlight, 27, 47-50.

GOVERNMENT OF UK (2018). Industrial Strategy Artificial Intelligence Sector Deal, www.gov.uk/beis (Erișim Tarihi: 11.08.2021).

HAAGA, H. (2019). The Influence of ICT on The Accommodation Industry in The Upcoming Industry 5.0. The Unpublished Postgraduate Thesis.

HARAYAMA, Y. (2017). Society 5.0: Aiming for a New Human-centered Society. Collaborative Creation through Global R\&D Open Innovation for Creating the Future, Hitachi Review. 66(6), 8-13.

İ-SCOOP (2018). From Industry 4.0 to Society 5.0: The Big Societal Transformation Plan of Japan. https://www.i-scoop.eu/industry-4-0/society-5-0/ (Erişim Tarihi: 23.08.2021)

İSO (2020). ISO, "Türkiye'nin 500 Büyük Sanayi Kuruluşu 2018" Araştırmasını Açıladı. http://www.iso.org.tr/haberler/diger-haberler/isoturkiyenin-500-buyuk-sanayi--kurulusu-2018-arastirmasini-acikladi/ (Erişim Tarihi: 28.08.2021)

JAPAN CABINET OFFICE. (2020). Society 5.0. https://www8.cao.go.jp cstp/english/society5 0/index.html (Erișim Tarihi: 29.08.2021).

KEIDANREN. (2016). Toward Realization of The New Economy and Society. Reform of The Economy and Society by The Deepening of "Society
5.0”. April 19. http://www.keidanren.or.jp/en/policy/2016/029 outline.pdf (Erişim Tarihi: 21.07.2021)

KEIDANREN. (2018). Society 5.0 - Co Creating the Future. Keidanren Policy \& Action. https://www.keidanren.or.jp/en/policy/2018/095_proposal. pdf (Erișim Tarihi: 04.09.2021)

KELLELIOĞLU, M. (2018). Toplum Eneriisini Nereye Harclyor? Toplum 5.0'dan Ne Kadar Haberdartz? https://www.mehmettekelioglu. com/2018/11/toplum-enerjisini-nereye-harciyor-toplum-5-0dan-ne-kadarhaberdariz/ (Erişim Tarihi: 15.08.2021)

KENT, E. (2019). Endüstri 4.0'dan Toplum 5.0'a. Türkiye'nin Endüstri 4.0 Platformu, https://www.endustri40.com/endustri-4-0dan-toplum-5-0a/ (Erişim tarihi: 01.08.2021)

KÖSEOĞLU, Ö. \& DEMIRCI, Y. (2018). Akıllı Şehirler ve Yerel Sorunların Çözümünde Yenilikçi Teknolojilerin Kullanımı. International Journal of Political Studies. 4(2), 40-57.

LOM, M., PRIBYL, O. \& SVITEK, M. (2016). Industry 4.0 as a Part of Smart Cities. Smart Cities Symposium, Prague, 1-6.

LUCKE J. V. (2016). Smart Government - The Potential of Intelligent Networking in Government and Public Administration. Conference Proceedings Book for E-Democracy and Open Government (CeDEM), 137-144.

MAZUR, O. (2019). Taxing the Robots. Pepperdine Law Review. 46(277), 277-330.

OECD (2002), Reviews of Regulatory Reform: Turkey 2002. Crucial Support For Economic Recovery, Paris.

OKAN GÖKTEN, P. (2018). Karanlıkta Üretim: Yeni Cağda Maliyetin Kapsamı. Muhasebe Bilim Dünyası Dergisi, 20(4), 880-897.

PETROV O. (2014). Open Data as a Key Enabler of Smart Government Session 3: Leveraging Emerging Technologies, 17th National Conference on e-Governance Kochi, India, https://nceg.gov.in/sites/default/files/nceg2014/ presentation/day1_session3_World_Bank_Oleg_Petrov.pdf (Erişim Tarihi: 18.07.201)

PRIME MINISTER OF JAPAN AND HIS CABINET (2017). Address by Prime Minister Shinzo Abe at CeBIT Welcome Night. Speeches and Statements by the Prime Minister, March 19, https://japan.kantei.go.jp/97 abe/ statement/201703/1221682_11573.html (Erişim Tarihi: 10.09.2021).

SAIF OBAID ALHEFEITI, F. (2018). Society 5.0: A human-centered society that balances economic advancement with the resolution of social problems by a system that highly integrates cyberspace and physical space. Unpublished Postgraduate Thesis. The British University in Dubai.

SARACEL, N. \& AKSOY, I. (2020). Toplum 5.0: Süper Ak1llı Toplum. Social Sciences Research Journal, 9(2), 26-34.

SERTAÇ ARI, E. (2021). Süper Akıllı Toplum: Toplum 5.0. Dokuz Eylül Üniversitesi Sosyal Bilimler Enstitüsü Dergisi, 23(1), 455-479.

SHIROISHI, Y., UCHIYAMA, K. \& SUZUKI, N. (2018). Society 5.0: For Human Security and Well-Being. IEEE Computer Society, November, 73-78.

T.C. BORNOVA BELEDIYESI (2019). En Iyi Vizyon Projesi Dijital Sinlf ve Altın Bilezik. https://bornova.bel.tr/2019/11/08/en-iyi-vizyon-projesi-dijital-

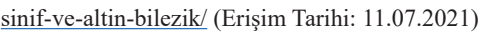

T.C. ÇEVRE VE ȘEHIRCILIK BAKANLIĞI (2019). 2020-2023 Ulusal Akıllı Şehirler Stratejisi ve Eylem Planı. https://www.akillisehirler.gov.tr/ (Erişim Tarihi: 12.07.2021).

TAMER, H. Y. \& ÖVGÜN, B. (2020). Yapay Zeka Bağlamında Dijital Dönü- 
şüm Ofisi. Ankara Üniversitesi SBF Dergisi, 75(2), 775-803.

THE GOVERNMENT OF JAPAN. (2019). Realizing Society 5.0., https:// www.japan.go.jp/abenomics/_userdata/abenomics/pdf/society_5.0.pdf (Accessed Date: 10.07.2021).

TINHOLT, D., ENZERINK, S., STRÄTER, W., HAUTVAST, P. \& CARRARA, W. (2017). Unleashing the potential of Artificial Intelligence in the Public Sector. Capgemini Consulting Report, www.capgemini-consulting. com, (Erişim Tarihi: 23.08.2021).

TURAN, D. (2020). Ekonomik ve Mali Boyutlarıyla Robot Vergisi. Anadolu Üniversitesi Sosyal Bilimler Dergisi, 20(1), 57-70.

TÜBITAK. (2016). Yeni Sanayi Devrimi Akıllı Üretim Sistemleri Teknoloji Yol Haritasl. https://www.tubitak.gov.tr/sites/default/files/akilli_uretim_sistemleri tyh_v27aralik2016.pdf (Erişim Tarihi: 24.08.2021).

TÜRK EĞITIM DERNEĞİ. (2020). Toplum 5.0: Insan Merkezli Toplum. 22 May1s, 1-11, https://tedmem.org/download/toplum-5-0-insan-merkezli-toplum?wpdmdl=3362\&refresh=613fb9d85972d1631566296 (Erişim Tarihi: 20.08.2021).

UÇMA UYSAL, T. \& ALDEMIR, C. (2018). Dijital Kamu Mali Yönetim Sistemi ve Blok Zinciri Teknolojisi. Muhasebe ve Vergi Uygulamalarl Dergisi, 11(3), 505-522.

YILDIZ Y. (2019). Robot Vergisi: Yeni Nesil Bir Maliye Politikası Aracı. Maliye Dergisi, 177 (Temmuz-Aralık), 299-329. 